\title{
Comparison of broiler breeder production and fertility in a colony cage system with two different floors versus a slat-floor system
}

\author{
Joseph Wayne Massey \\ West Virginia University
}

Follow this and additional works at: https://researchrepository.wvu.edu/etd

\footnotetext{
Recommended Citation

Massey, Joseph Wayne, "Comparison of broiler breeder production and fertility in a colony cage system with two different floors versus a slat-floor system" (2002). Graduate Theses, Dissertations, and Problem Reports. 703.

https://researchrepository.wvu.edu/etd/703

This Thesis is protected by copyright and/or related rights. It has been brought to you by the The Research Repository @ WVU with permission from the rights-holder(s). You are free to use this Thesis in any way that is permitted by the copyright and related rights legislation that applies to your use. For other uses you must obtain permission from the rights-holder(s) directly, unless additional rights are indicated by a Creative Commons license in the record and/ or on the work itself. This Thesis has been accepted for inclusion in WVU Graduate Theses, Dissertations, and Problem Reports collection by an authorized administrator of The Research Repository @ WVU. For more information, please contact researchrepository@mail.wvu.edu.
} 


\title{
Comparison of Broiler Breeder Production and Fertility in a Colony Cage System with Two Different Floors Versus a Slat-Floor System
}

\author{
Joseph W. Massey \\ Thesis Submitted to the \\ Davis College of Agriculture, Forestry, and Consumer Sciences \\ At West Virginia University \\ In partial fulfillment of the requirements for the degree of \\ Master of Science \\ In \\ Animal and Veterinary Sciences \\ Ronald A. Peterson, Ph.D., Chair \\ Hillar Klandorf, Ph.D. \\ Brett Kenney, Ph.D.
}

Division of Animal and Veterinary Sciences

Morgantown, West Virginia

2002

Keywords: Broiler Breeders, Fertility, Production, Mortality 


\section{Abstract \\ Comparison of Broiler Breeder Production and Fertility in a Colony Cage System Versus Floor System \\ Joseph W. Massey}

Two separate trials were conducted to compare egg production, egg weight, shell thickness, albumin height, fertility, and mortality of naturally mated broiler breeders maintained on either a slat and litter floor or in two tiered colony cages. In the first trial there was no difference $(\mathrm{P}>0.05)$ in egg production between the two treatments. There was also no significant difference in hen mortality. Higher $(\mathrm{P}<0.05)$ egg shell quality, albumin height, and shell thickness were observed in the cage maintained hens. Lower fertility $(\mathrm{P}<0.05)$ was observed in the cage maintained hens. In the second trial production parameters were compared in naturally mated broiler breeders maintained on slat and litter floor, in colony cages on the original slats, and in colony cages on a modified slats. The modified slats were constructed from plastic and had a two piece design which produced a slight cushioning on the top of the slats. Egg production and mortality were not different $(\mathrm{P}>0.05)$ among the three treatments. Eggshell thickness, albumin height, and shell thickness were lower $(\mathrm{P}>0.05)$ in the litter and slat floor but not between the two cage treatments $(\mathrm{P}>0.05)$. Fertility was higher $(\mathrm{P}<0.05)$ in the litter and slat floors, but different $(\mathrm{P}>0.05)$ between the two cage treatments. Future studies to improve fertility in colony cage maintained broiler breeders could allow increased stocking rates in existing broiler breeder houses. 


\section{Acknowledgements}

I would like to thank my wife and family, for all their patience, support, and the sacrifices they withstood throughout the entire process. I could not have accomplished this task without them. I would also like to thank Dr. Peterson for giving me the opportunity to pursue my Masters degree. I would like to thank Dr. Klandorf and Dr. Kenney for their patience and understanding during this process. I would also like to thank all the professors in the Animal and Vet. Science department. I could go to any of them with a question, and they would work hard to help me find the answer. I would like to thank Dr. Thane for helping me with the statistical work. Last but not least I would like to thank God for making it all possible. 


\section{Table of Contents}

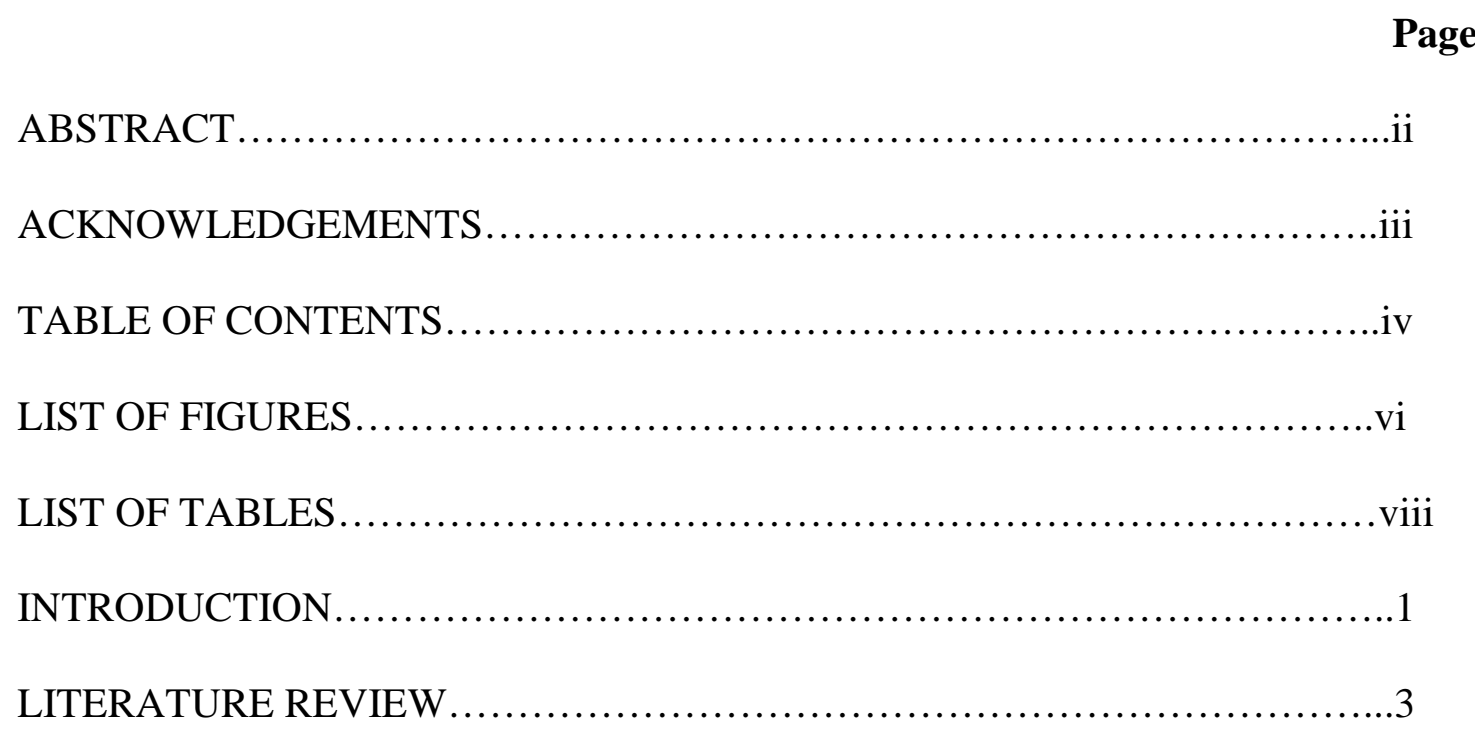

Broiler Breeder Production Systems....................................

History.........................................................

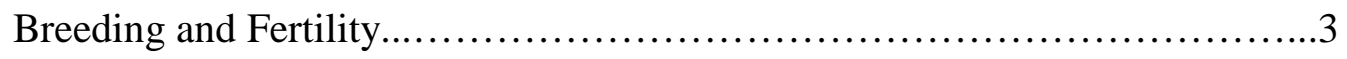

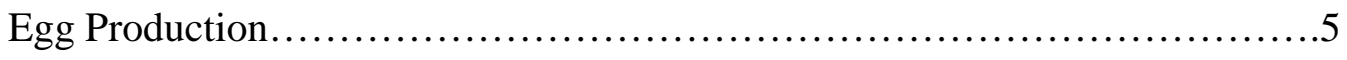

Cage versus Floor Management.....................................6

Effects of Egg Size...............................................

Conclusion of Literature Review...................................

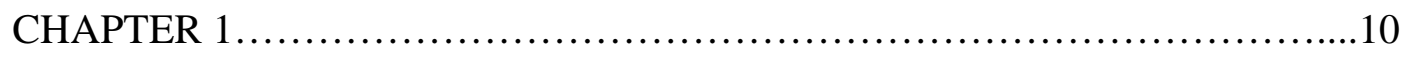

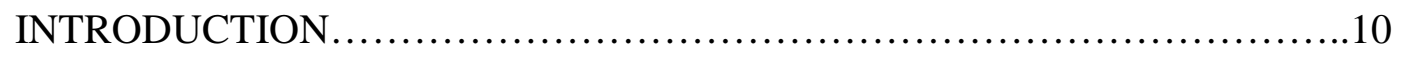

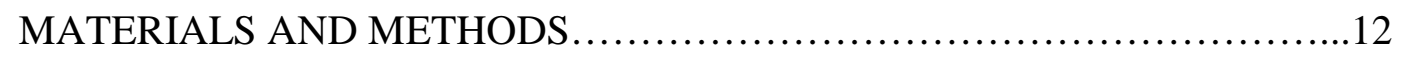

DATA COLLECTION................................................ 14

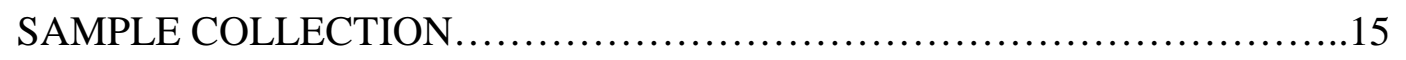

STATISTICAL ANALYSIS ........................................ 16

RESULTS....................................................... 17 
First Experiment.................................................17

Second Experiment...................................................21

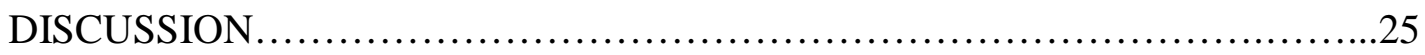

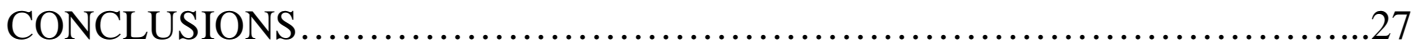

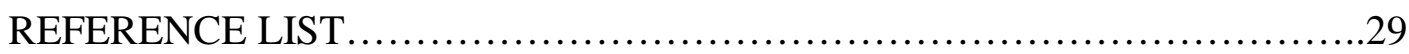

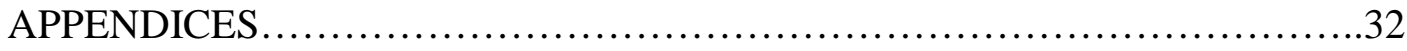

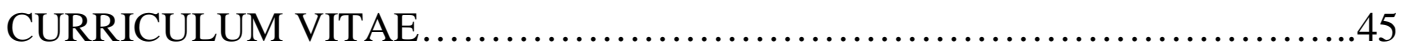




\section{List of Figures}

Figure

Page

1.1. Average weekly fertility for hens managed in slat-floor pens versus colony cages

1.2. Average weekly fertility for hens maintained in slat-floor pens versus colony cages.

1.3. Average mortality comparing slat-floor pens and colony cage maintained hens. 32

1.4. Average mortality comparing slat-floor and colony cage maintained Roosters

1.5. Average egg weights for hens managed in slat-floor pens versus colony cages.

1.6. Average albumin height of eggs produced in slat-floor pens versus colony cages.

1.7. Average shell thickness of eggs produced in slat-floor pens versus colony cages..................................................... 36

1.8. Comparison of fertility of eggs produced in slat-floor pens versus colony cages

1.9. Average eggs per hen housed comparing slat-floor pens and colony cages.

2.1. Average weekly egg production comparing slat-floor colony cages with original floors and colony cages with modified floors

2.2. Average weekly fertility comparing slat-floor, colony cages with original floors, and colony cages with modified floors

2.3. Hen mortality percentages comparing slat-floor pens, modified floor colony cages, and original floor colony cages

2.4. Average weight of eggs produced in slat-floor pens, modified floor colony cages, and original floor colony cages

2.5. Average albumin height of eggs produced in slat-floor pens, modified 
floor colony cages, and original floor colony cages...................4

2.6. Average egg shell thickness of eggs produced in slat-floor pens, modified floor colony cages, and original floor colony cages............42

2.7. Comparison of fertility of eggs produced in slat-floor pens, modified floor colony cages, and original floor colony cages.............43

2.8. Comparison of egg production from hens managed in slat-floor pens, modified floor colony cages, and original floor colony cages.........44 


\section{List of Tables}

Table

Page

1.1 Experiment 1 mortality, egg quality, and production measurements............18

2.1 Experiment 2 mortality, egg quality, and production measurements...........22 


\section{Introduction}

Broiler breeder chickens are the parent birds used to produce broilers, which are the chickens grown for slaughter by producers and poultry companies. In the United States, the customary management method for breeders during their egg production cycle is the use of slat and floor pen systems. The birds are allowed access either large areas or the entire area inside a broiler breeder facility. Feed and water are offered to the chickens over slatted areas to ease collection of feces and minimize nest contamination. The fecal material remains under the slats until the chickens are removed from the house after approximately 320 days of egg production. Nests are conventionally offered to the broiler breeder hens by placing two rows of nests, two high, down the center of the house. This creates a floor space allocation of approximately 2.5 square feet per bird, available space being the limiting factor in determining the total number of birds in a broiler breeder house. Fulfilling this requirement affects potential income the producer can realize from this broiler breeder house.

The use of colony cages stacked two high can almost double the number of chickens that can be placed into a barn, and thereby almost double the income potential to the producer, provided it can be accomplished without a decrease in egg quality, egg production, or fertility, or an increase in mortality. Colony cages do not require nests. They have a self-contained nesting area that does not eliminate floor space. The eggs that are laid roll down the sloped floor to a collection area. Furthermore, the floors of the colony cages are slatted to allow fecal droppings to fall through onto a belt where they can be removed from the house as frequently as the producer desires. 
The objective of this study was to determine if colony cages represent a viable alternative for broiler breeder operations when natural mating is used by monitoring 1). egg quality, 2). egg production, 3). fertility, and 4). mortality.

Because of increasing construction and production costs, and considering waste management issues here in the United States, more information on alternative production methods is needed for poultry producers. 


\section{Literature Review}

\section{Broiler Breeder Production System}

\section{History}

The first avian species domesticated was the red jungle fowl. Initially, the selection process for these fowl was focused on fighting behavior for the entertainment of their captors. The Romans eventually discovered much later that the fowl, once domesticated, offered them a source of meat and eggs, which added to the nutrition of the people (Appleby, et al., 1993).

\section{Breeding and Fertility}

In broiler breeders, genetically different breeds have been combined to maximize hybrid vigor, especially as it applies to growth in their offspring. Females are bred to produce fairly large numbers of eggs that hatch well, yet the birds are large and genetically have good growth-promoting characteristics (North \& Bell, 1990). Selection criteria for broiler breeders include rapid feathering, meat yields, and feed conversion. In broiler breeders, which are the parents of the broilers, egg production, egg quality, and hatchability must also be selected for in the hens. Parent birds must go through their production cycle while they are feed restricted to keep their body weight from increasing too fast. Bilgilli and Renden (1985) reported that body weight was positively correlated with body fat and oviduct fat and that both body weight and body fat were negatively correlated with fertility, although oviduct fat was not significantly correlated with this variable. Fasenko et al. (1992) also reported that fertility and hatchability 
decline as hen weight increases. They observed that embryos from first eggs in a sequence were more developed than embryos from subsequent eggs, even though the first eggs were not as viable. Atwood (1929) and Robinson et al., (1990) found that egg production, fertility, and hatchability decrease with age. In addition, Yu et al. (1992) reported that egg fertility and hen body weight is inversely related. Once the hens' optimum weight is surpassed at a given age, fertility is reduced.

Bramwell et al., (1996) compared artificially inseminated and naturally mated flocks in experiments to determine the effect of age on sperm penetration into the perivitelline layer overlaying the germinal disc. In the artificially inseminated hens, sperm penetration was lower in older hens when compared with younger hens, regardless of the age of the roosters. When semen from older roosters was inseminated into younger hens, there was an increase in semen penetration in the perivitelline layer. In naturally mated hens fertility decreased with the increasing flock age due to physiological conditions of individual hens. It was also concluded that fertility declined with the male's advancing age due to physical problems. These problems include rooster mating competition, physical injuries, and decreased libido due to aging. Thus both increased body weight and age reduce fertility in broiler breeders.

In another study, Parker and McClurskey (1959) reported that semen volume per ejaculate was not significantly different between egg type roosters in cages versus floor reared birds. However, percent of fertile eggs from hens inseminated by using semen from cage males was higher than the percent of fertile eggs. 


\section{$\underline{\text { Egg Production }}$}

Robinson et al. (1996) compared the effect of increasing day length on broiler breeder pullets in cages that had previously received 8 hours of light each day. This was performed to study the effects on age at sexual maturity, egg weight, average hatchability, and fertility. Treatments received a 12 hour photo period at $120,130,140$, 150 , and 160 days of age. They reported that as pullets' age increased prior to photo period stimulation, age at sexual maturity decreased. However, there were no significant differences when comparing first egg weight, average hatchability, and fertility. Egg production was higher in 140, 150, and 160-day-old photo stimulated birds, and these birds reached sexual maturity with better flock uniformity than those photo stimulated at an earlier age.

McDaniel et al. (1981) reported that body weight was negatively correlated with egg hatchability and shell quality. They also reported a significant positive correlation between eggshell quality and fertility. Fertility was positively correlated with hatchability and hen-day production.

Fuquay and Renden (1980) determined that broiler breeders maintained in cages weighed more and laid fewer eggs per day than broiler breeders maintained in floor pens. Fertility and hatchability were improved for broiler breeders in cages with artificial insemination than those naturally mated and maintained on the floor.

According to Petitte et al. (1982) broiler breeders maintained in cages produce heavier eggs than those managed on litter floors. Petitte et al. (1983) compared production efficiency of broiler breeders artificially inseminated in cages to those naturally mated in floor pens. No difference was found between the two when comparing early embryonic 
death; although the hatchability of the eggs from cages was significantly lower during subsequent trials.

\section{Cage versus Litter Floor Management}

According to Petitte et al. (1982) broiler breeders housed in cages produce heavier eggs than those managed on litter floors. Also (Petitte et al., 1983), a comparision of production efficiency of broiler breeders artificially inseminated in cages to those naturally mated in floor pens demonstrated no difference embryonic death, although hatchability was significantly lower in the eggs collected in the cages.

Fuquay and Radden (1980) compared the performance of broiler breeders maintained in cages versus litter floors. In the first study, semen samples were collected from the males weekly between 36 and 60 weeks of age. Broiler breeder females were placed in cages either individually or in pairs. Males were individually caged and semen was collected 3, 5, and 10 times per week. Females were inseminated with semen from known male breeders. No significant differences were observed in semen volume and concentration from breeder roosters up to 59 weeks of age. Total sperm count per ejaculate was higher from males ejaculated 5 times per week, as compared to 3 and 10 times per week.

In a second study, female broiler breeders were assigned to floor pens with male to female ratios of 1:25, 2:25, and 3:25 for natural mating. Eggs were collected for 7 days. The experiment did not find any difference in fertility and hatchability among any of the treatments.

Petitte et al. (1982) tested the uniformity of body weight in broiler breeders maintained on litter versus cages. There were no differences in productive performance among flocks of $80 \%$ and $89 \%$ of body weight uniformity. Although caged broiler breeders 
produced more eggs during peak egg production, cumulative egg production was not significantly different. They also reported that naturally mated boiler breeders maintained on the floor had a significantly higher fertility rate than those artificially inseminated in cages. This observation is not in agreement with the study by Lessen and Summers (1985) who reported no difference between broiler breeders housed in cages versus floors.

\section{Effects of Egg Size}

Tindell and Morris (1964) studied the effect of egg weight on subsequent broiler performance. They concluded that not only does fertility increase with egg size, but also the hatching weight of the chick. In a similar experiment, Proudfoot and Hullan (1981) observed no differences in fertility and hatchability between eggs weighing 53 grams and eggs weighing 49.97 grams. However, egg size was correlated with the chicks body size at 48 days of age which was slaughter age.

\section{Conclusion of Literature Review}

The increase in body weight of broiler breeders as they age is associated with a decline in hatchability, hen-day production, and shell quality. Fertility is also negatively correlated with body weight and fat deposition. Egg size increases with the age of the bird, which results in chicks maintaining a higher body weight for the first 12 weeks after hatching. Egg size is positively correlated with fertility and hatchability. The capability of semen to fertilize is not affected by increased broiler breeder body weight or age, but senescence and excessive weight reduces their libido and natural mating competitiveness. Mortality is similar between hens housed in cages and hens maintained on floors. 


\section{$\underline{\text { Nutrition }}$}

Nutrition for the broiler breeder must be carefully monitored and adjusted frequently because of the selection criteria for rapid growth. Thus, feed must be restricted to prevent excessive weight gain. In order to maximize performance, the caloric intake must be restricted through the entire growing period.

Restricting the feed will delay the onset of sexual maturity until such a time the broiler breeder pullets will lay an egg of sufficient size to be viable (North \& Bell,1990). This also produces better livability during egg production. There are two different types of feed restriction used in breeders. The first is called skip-a-day feeding. The breeders are given an allotted amount of feed every other day starting on the $29^{\text {th }}$ day after hatching. The feed amount is increased every week provided the breeders are not exceeding their target weight for that week. The target weight is usually determined by the company that supplies the chicks for the producer. These target weights are the result of research by the companies. If they have exceeded the target amount, the feed may not be increased the following week until they are once again at their target weight for that week. The target weight starts at $0.3 \mathrm{lbs}$. per chick at 1 week of age, and increases to $5.5 \mathrm{lbs}$. at 24 weeks of age. The nutritional components of the feed that are most important in broiler breeders are protein, vitamins, methionine, lysine, cystine, calcium, and phosphorus. Energy is also important since the level of energy in the diet will determine the amount of feed eaten to some extent. The starter ration the chicks are fed for the first four weeks of age contains $20 \%$ protein and $1275 \mathrm{kcal} \mathrm{ME}$ per $\mathrm{lb}$. of feed. It is then reduced to $18 \%$ protein and $1300 \mathrm{kcal}$ ME per lb of feed for weeks 5-9 since slower growth is wanted during this period. The protein level is further reduced again at week $10-15$ to $15 \%$ 
protein, while the energy level will remain the same throughout the remainder of the growout period. On week 16, the protein is again reduced to $12 \%$. The protein content is reduced to limit weight gain since protein is not required for growth during this period. At 23 weeks of age the protein level is increased to $16 \%$ since more protein is necessary during the egg production period. Calcium is required for egg shell production, and is increased prior to the onset of egg production. After 25 weeks of age, broiler breeders are fed a ration containing about $1300 \mathrm{kcal}$ ME per lb. of feed, 16\% protein, approximately $3 \%$ calcium, $0.46 \%$ available phosphorus, $0.78 \%$ lysine, $0.31 \%$ methionine, and $0.56 \%$ lysine+cystine. The methionine must be supplemented because the chickens cannot synthesize it themselves. Vitamins are always included in the rations at concentrations established by nutritionists based on the ingredients used in the rations.. 


\section{Chapter One: Introduction}

The production of hatching eggs from broiler breeders must be economical for the producer and the integrator they produce for. If egg production, fertility, mortality, and hatchability are not in an acceptable range, the producer and the company lose money. The public focus on the environment has also presented an additional challenge for the producer. The manure produced by the birds must be handled and applied in an environmentally acceptable manner. The current method of waste handling is not always timely with the needs of the crop produced. The waste is collected and spread on fields once the broiler breeders have completed their 320 day egg production cycle. This can occur at any time during the year depending on when they started their cycle. Energy costs are also greater than they were just a few years ago. The cost of building the broiler breeder house has also increased, along with the cost of the land. Finding locations suitable for their construction is growing more difficult each day as more and more people purchase farmland to build houses in the country, which drives up land prices.

Poultry companies in Europe are considering colony cage systems as a method of increasing stocking rates in existing houses, and reducing labor costs. This system provides a simpler method of waste handling that will permit application to crops when they are actively growing, instead of when the barns must be cleaned out at the end of a production cycle. In the colony cage system, waste is removed from the house on an almost daily basis and stockpiled or applied depending on the crop. Companies and producers in the United States have not embraced the colony cage system because of concerns about increased mortality, reduced fertility, reduced egg quality, and reduced production. Any one of these factors would increase the cost per egg produced. Since 
the profit margin is already marginal, any further reduction could not be tolerated.

However, if it can be established that broiler breeders can be housed in colony cages without a reduction in production, fertility, and egg quality, or an increase in mortality, the producers can offset the extra cost of the cages with an increased stocking rate and a decreased labor cost. 


\section{Materials and Methods}

\section{Experimental Procedure}

Two separate experiments were conducted to compare the effect of slat-litter pens and colony cage systems on egg production, mortality, fertility, and egg quality in broiler breeder hens. In the first experiment, 2,500 day old female and 500 day old male Hubbard Hi-Y chicks were placed on the Wardensville farm in a blackout poultry house during the growth phase, using management practices currently employed by poultry companies (Hubbard Farms, 1994). The females were placed in six identical pens and the males were placed in two identical pans for the first 20 weeks of age. Water was supplied to the chicks without restriction during the entire experiment. Nipple drinkers were used throughout the rearing and production phases. The first seven days they were fed a ration containing $18 \%$ protein and 2800 M.E. calories $\mathrm{kg}^{-1}$ ad libidum. After the second week feed restriction was performed. Feed was given each day. From 2 weeks of age during the growing period, 10 chicks from each pen were weighed at random to determine the average feed requirement for that week. From 12-19 weeks of age they were raised using the skip-a-day method of feed restriction using a ration containing $16 \%$ protein and 2920 M.E. calories $\mathrm{kg}^{-1}$. Two weeks before the onset of egg production (20 weeks of age), males and females were randomly selected and placed into one of four slat-litter pens or one of four, two tier colony cage units during the egg production phase. Extra birds were also housed in two slat-floor pens. The ration contained $16 \%$ protein and 2920 M.E. calories $\mathrm{kg}^{-1}$. Restricted feeding recommendations were obtained from the broiler breeder management guide (Hubbard Farms, 1994). Colony cage units were stocked at 168 females and 18 males per unit. Two, two-tier colony cage units occupied 
the same area as one slat-floor pen, resulting in a stocking rate of 336 females and 36 males. Slat-floor pens were stocked at a rate of 180 females and 18 males and occupied the amount of area. In the first experiment, all the slats in the colony cages were made of the same material. The slats were made of plastic, and were of a one piece design. In the second experiment half of the slats in the colony cage systems were replaced with a new type of slat. These slats were plastic but made of a two piece design which permitted the slat to afford some cushion to the birds. Extra roosters were kept in a spare slat-floor pen and were used to replace any roosters exhibiting sore foot pads in the second experiment. A forced air heating system was used to provide brooding heat. Chicks were started at a temperature of $90^{\circ} \mathrm{F}$. The temperature was lowered $5^{\circ} \mathrm{F}$ per week until a temperature of $70^{\circ} \mathrm{F}$ was reached. Twenty four hours per day of artificial light was given for the first three days. Twelve hours of light per day was given from day 4 through day 21 of age followed by eight hours of light until the birds were twenty weeks of age. Water was supplied ab libitum in all age groups using nipple drinkers.

At 20 weeks of age, 168 pullets and 18 cockerels were randomly selected for placement in each two-tiered colony cage unit giving a 1:9.3 male to female ratio. This ratio allowed 3 males to be housed in each section, giving 3 males per 28 females. Each level had three separate sections, each measuring 2 meters long, 1.05 meters wide, and 0.7 meters high that housed 28 pullets and 3 cockerels. Each unit is watered by nipple drinkers and has a roost that runs down the center. Birds were spaced at slightly more than 13 birds per $\mathrm{m}^{2}$ or $0.07 \mathrm{~m}^{2}$ per bird. The skip-a-day feed restriction program was continued until the first egg was laid at 25 weeks of age, at which time a restricted daily feeding was adopted based on the average hen weight. Hens were allowed to feed 
anywhere in the automated feeding system but males were limited to four feeding locations per section by feeder grills to restrict their intake. Each section also had a darkened gray colored laying area at one end measuring 0.4 meters long, 1.05 meters wide, and 0.7 meters high.

To compare colony cages to slat-litter floor pens when using natural mating, 180 pullets and 18 cockerels were randomly selected from the same growout pens used to supply the colony cages. These broiler breeders were placed in 4 conventional floor pens, each unit measuring 8.9 meters long, 4.4 meters wide, and 2.5 meters high, Making a spacing of 5 birds per $\mathrm{m}^{2}$, or $0.2 \mathrm{~m}^{2}$ per bird. Hens were fed using an automated system with grills that prevented access by the males. Males were hand fed each morning in two tube feeders raised to prevent hens from feeding from them. Feeding, watering, and lighting regimes were similar for both floor and cage treatments.

In the second experiment, the same number of birds were used in the slat-floor pens and the colony cages. However, half of the slats in the colony cage systems, two top tier and two bottom tier sections, were changed to include a modified slat in an attempt to increase fertility. These modified slats were made of a two piece plastic construction which absorbed some of the impact on the broiler breeders feet. The top edge of the slats were manufactured as a separate piece, which allowed it to flex slightly downward when weight or impact contacted it. They were also spaced slightly closer together than the original slats. Males exhibiting sore footpads in all treatments were removed and healthy males of the same age were used as replacements. 


\section{Sample Collection and Transport}

Eggs were gathered 3 times each day from each treatment for 25 weeks. Ten egg samples were obtained randomly from each replication on Wednesday of each week for measurement of egg quality. Ten sample eggs per replication were also randomly taken for fertility testing each week, which was performed on the farm. Egg quality samples were stored for one day in the egg cooler and returned to the lab so egg weights, interior egg quality and shell thickness could be recorded. Eggs taken for fertility sampling were also stored in the egg cooler for 1 day before they were placed into the incubator. All sample eggs were placed in flats numbered to show which pen or colony cage unit and level they came from prior to placement into the egg cooler. These samples were boxed the following day after they had cooled and transported to the lab for analysis. They were handled and stored in the same manner as they would by industry.

\section{Analysis of Samples}

Fertility of the eggs was tested at the farm by incubating the sample eggs in a Jamesway incubator at the farm for ten days, then breaking them out to determine fertility. If the egg contained an embryo that had progressed to a point that could be seen with the naked eye, it was considered fertile. Egg samples for egg quality measurement were stored in an egg cooler for 24 hours at 55 degrees $\mathrm{F}$ and $65 \%$ humidity, then were transported to the lab. These samples were first tested for weight by using a specially designed egg scale manufactured by Technical services and Supplies and readings were taken in grams of weight. Each egg was then broken open so albumin height could be determined using a Albumin height and Haught device, manufactured by Technical Services and Supplies. This instrument uses a probe mounted on a tripod, when the 
probe makes contact with the albumin, a reading is given in Haught units so a comparison can be made between eggs. The larger the Haught unit number, the better the albumin quality. Measurements were taken on the rise of the albumin near the yolk. After the albumin height was recorded, the shells from these eggs were then measured to determine shell thickness. All shells were measured using a micrometer with the membranes in, at the region of the largest diameter of the egg between the large and small end.

\section{Statistical Analysis}

Data for both experiments analyzed by using the General Linear Model (GLM) procedure (SAS Institute, 1991). The main effects studied in the model are the effects of housing and time. The statistical significance was based on a probability of $\mathrm{P}<0.05$. In the first experiment the colony cages had 8 replications, each housing 168 females and 18 males. The slat-floor pens had 4 replications, each housing 180 females and 18 males. In the second experiment the original floor colony cages had 4 replications, each housing 168 females and 18 males. The modified colony cages also had 4 replications housing 168 females and 18 males. The slat-floor pens had 4 replications housing 180 females and 18 males. 


\section{Results}

\section{Experiment One}

\section{Mortality Rates}

Hen mortality rates at the end of the 25 week study between the two treatments were not different $(\mathrm{P}>0.05)$. Hen mortality averaged $14.9 \%$ in the slat-litter pens and $13.6 \%$ in the colony cages. The mortality rate for the roosters in the slat-litter pens was $16.6 \%$, while only $9.7 \%$ for the colony cages.

\section{Egg Quality Measurements}

Egg weights for the cage birds (Figure 1.1) were higher than that measured in the floor pens $(\mathrm{P}<0.05)$. Egg weights for the slat-floor pens averaged 64.4 grams per egg and 68.7 grams per egg in the colony cages. Average albumin height measurements were also higher $(\mathrm{P}<0.05)$ in the cage birds than in the floor pens (Figure 1.3). Eggs obtained from birds maintained in slat-floor pens averaged 5.7 Haught units in albumin height versus 6.2 Haught units for colony cages. Average eggshell thickness (Figure 1.2) were higher in the colony cages $(\mathrm{P}<0.05)$ when compared to the slat-floor pens. Egg shells from slatfloor pens averaged $0.12355 \mathrm{~mm}$ compared to $0.12633 \mathrm{~mm}$ in colony cages.

\section{Fertility and Egg Production}

Fertility rates for the floor pens were higher, averaging $89.9 \%$ compared to $82.4 . \%$ in the colony cages (Figure 1.4). Hen housed egg production was not significantly different when comparing conventional floor systems and colony cages (figure 1.5) 


\section{Comparison of Colony Cages Versus Slat-Floor Pens Experiment 1}

Item Measured (average)

Hen Mortality (\%)

Rooster Mortality (\%)

Egg Weights (gm)

Albumin Height (Haugh units)

Shell Thickness (mm)

Fertility (\%)

Eggs Per Hen Housed Production
Colony Cages

$13.6^{\mathrm{a}}$

$9.7^{\mathrm{a}}$

$68.7^{\mathrm{a}}$

$6.2^{\mathrm{a}}$

$0.126^{\mathrm{a}}$

$82.5^{\mathrm{a}}$

$106.5^{\mathrm{a}}$
Slat-Floor Pens

$14.9^{\mathrm{a}}$

$16.6^{\mathrm{b}}$

$64.4^{\mathrm{b}}$

$5.7^{\mathrm{b}}$

$0.123^{b}$

$89.9^{\mathrm{b}}$

$107.4^{\mathrm{a}}$

* Measurements with different superscripts are significantly different at $\mathrm{P}<0.05$.

Table 1.1 


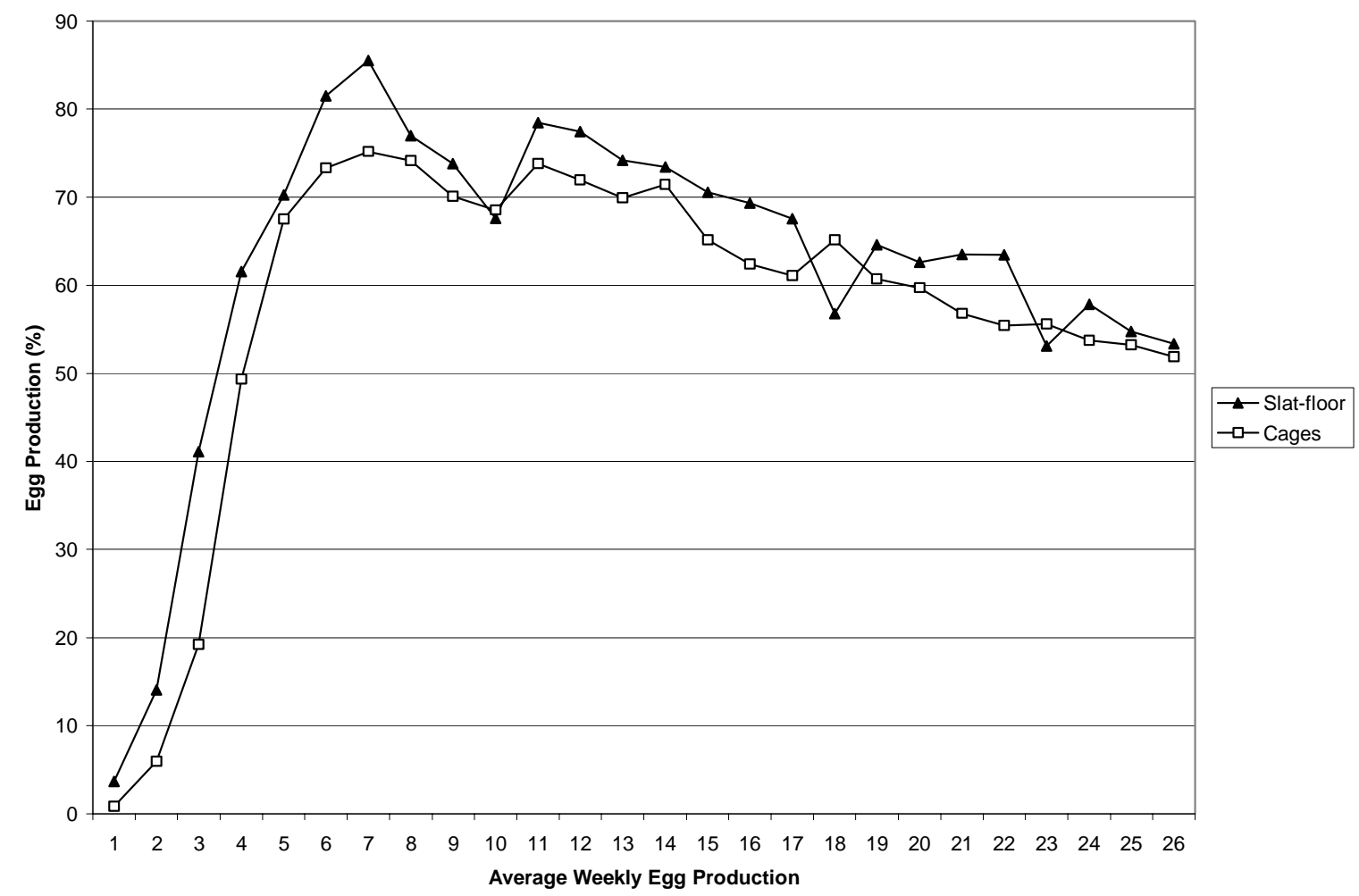

Figure 1.1. Average weekly egg production comparing slat-floor pens and colony cages. 


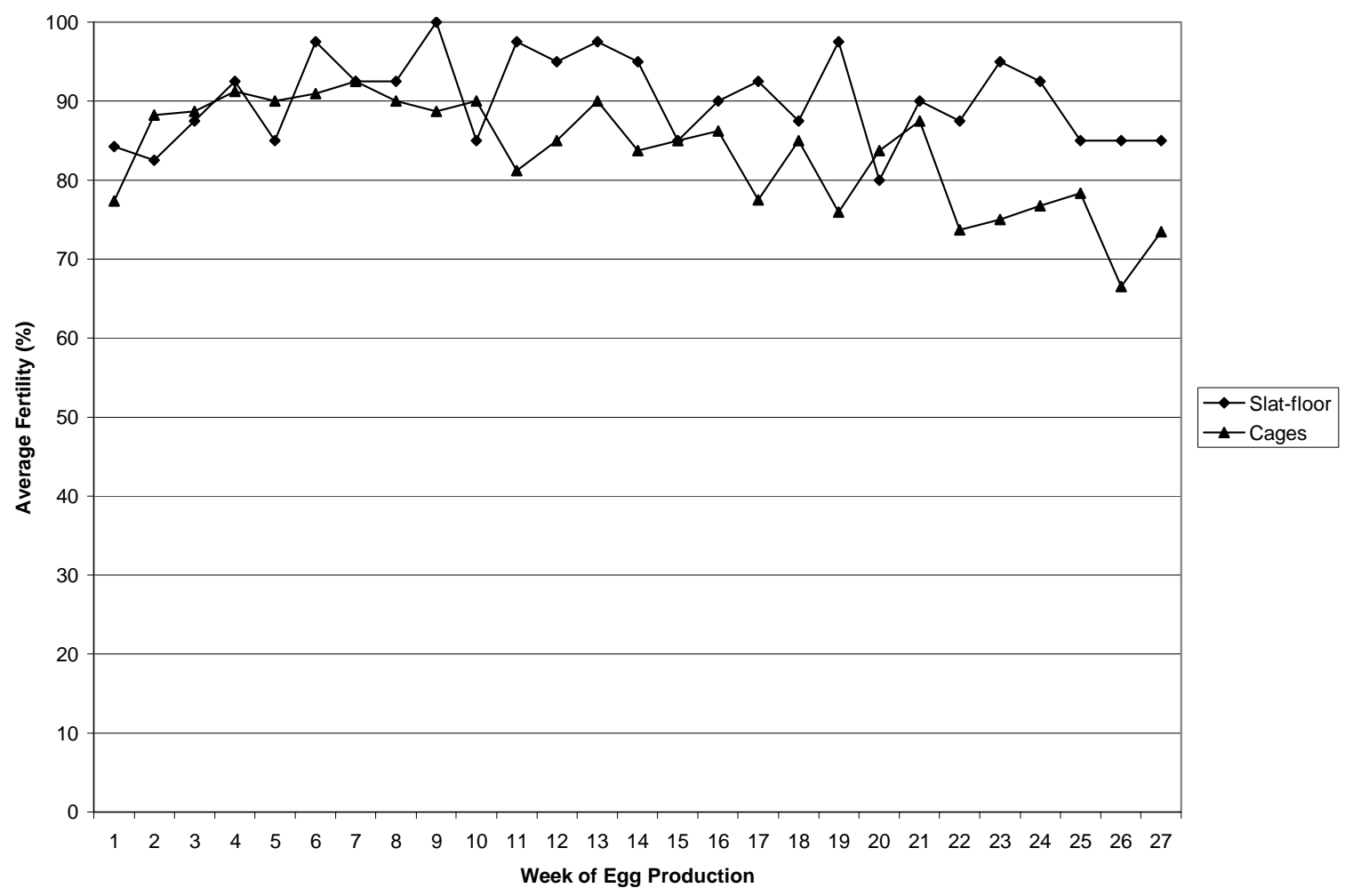

Figure 1.2. Average weekly fertility comparing slat-floor pens and colony cages. 


\section{Experiment 2}

In experiment 2 , floor pens (FP), colony cage units with the original flooring (OF), and colony cage units with a modified flooring (NF) were compared. The same observations were recorded with the exception of male mortality.

\section{Hen Mortality}

Hen mortality was not different $(\mathrm{P}>0.05)$ between the FP, NF, and OF treatments. Hen mortality averaged $6.5 \%$ for the slat-floor treatment, $4.7 \%$ for the modified floor cage treatment, and $5.0 \%$ for the original floor cage treatment. Rooster mortality was not recorded in experiment 2 because males were replaced as needed throughout the experiment in all treatments.

\section{Egg Quality}

The egg weights for the FP treatment were lower $(\mathrm{P}<0.05)$ than egg weights for both the NF and the OF treatment (Figure 2.2). Average weights for the FP treatment were 66.2 grams, the NF treatment averaged 67.9 grams, and the OF treatment averaged 67.5 grams. The NF and OF treatments were not significantly different from each other. Measurements of albumin height were lower $(\mathrm{P}<0.05)$ in the FP treatment than either the NF or OF treatments (Figure 2.3). The FP treatment averaged 5.2 Haught units, the NF treatment averaged 5.9 Haught units, and the OF treatment averaged 5.9 Haught units. $\mathrm{NF}$ and OF treatments were not significantly different. Shell thickness averages were significantly different between the FP treatment $(\mathrm{P}<0.05)$ and both the NF treatment and the OF treatment (Figure 2.4). The slat-floor treatment averaged $0.124 \mathrm{~mm}$, the modified colony cage floor treatment averaged $0.126 \mathrm{~mm}$, and the original floor colony cages averaged $0.126 \mathrm{~mm}$. The two colony cage treatments were not significantly different. 


\section{Fertility and Egg Production}

The fertility for the FP treatment was significantly higher $(\mathrm{P}<0.05)$ than in either of the cage treatments. Fertility averaged $89.2 \%$ for the slat-floor treatment, $84.4 \%$ for the modified floor colony cage treatment, and $82.2 \%$ for the original floor colony cage treatment. Cage treatments were not significantly different from each other. Egg production was not different $(\mathrm{P}>0.05)$ between the three treatments. The FP treatment averaged 109.4 eggs per hen housed, the modified floor colony cage treatment averaged 108.9 eggs per hen housed, and the original floor colony cage treatment averaged 108.8 eggs per bird.

\section{Comparison of Colony Cages Versus Slat-Floor Pens Experiment 2}

Item Measured (average) $\mathrm{OF}$ NF FP

Hen Mortality (\%)

Egg Weights (gm)

Albumin Height (cm)

Shell Thickness (mm)

Fertility (\%)

Eggs Per Hen

Housed Production $5.0^{\mathrm{a}}$

$67.5^{\mathrm{a}}$

$5.9^{\mathrm{a}}$

$0.126^{\mathrm{a}}$

$82.2^{\mathrm{a}}$

$108.8^{\mathrm{a}}$ $4.7^{\mathrm{a}}$

$67.9^{\mathrm{a}}$

$5.9^{\mathrm{a}}$

$0.126^{\mathrm{a}}$

$84.4^{\mathrm{a}}$

$108.9^{\mathrm{a}}$ $6.5^{\mathrm{a}}$

$66.2^{\mathrm{b}}$

$5.2^{\mathrm{b}}$

$0.124^{b}$

$89.9^{\mathrm{b}}$

$109.4^{\mathrm{a}}$

\footnotetext{
* Measurements with different superscripts are significantly different at $\mathrm{P}<0.05$.
}

\section{Table 2.1}




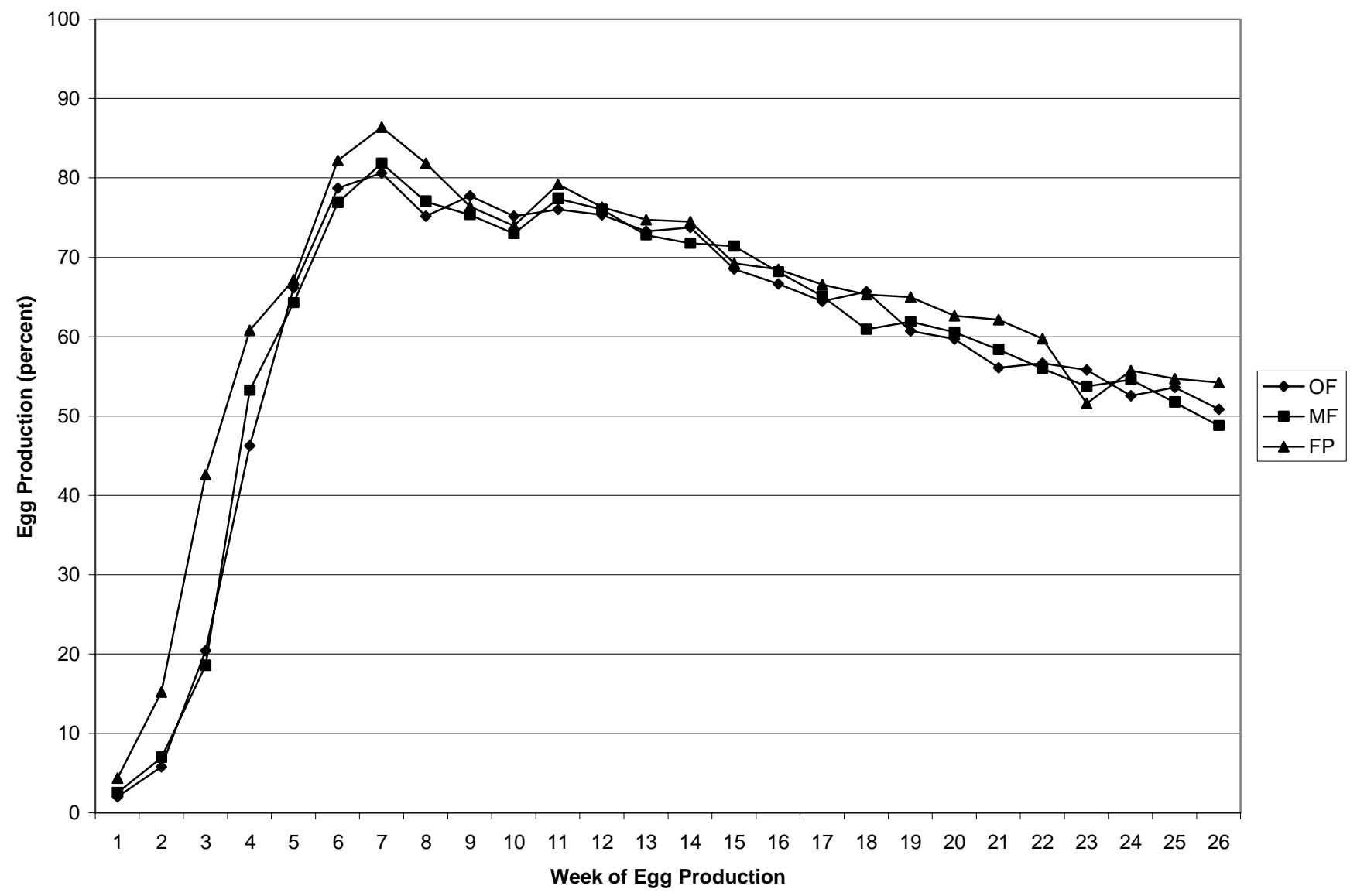

Figure 2.2. Average weekly egg production comparing slat-floor pens, colony cages with original floors, and colony cages with modified floors. 


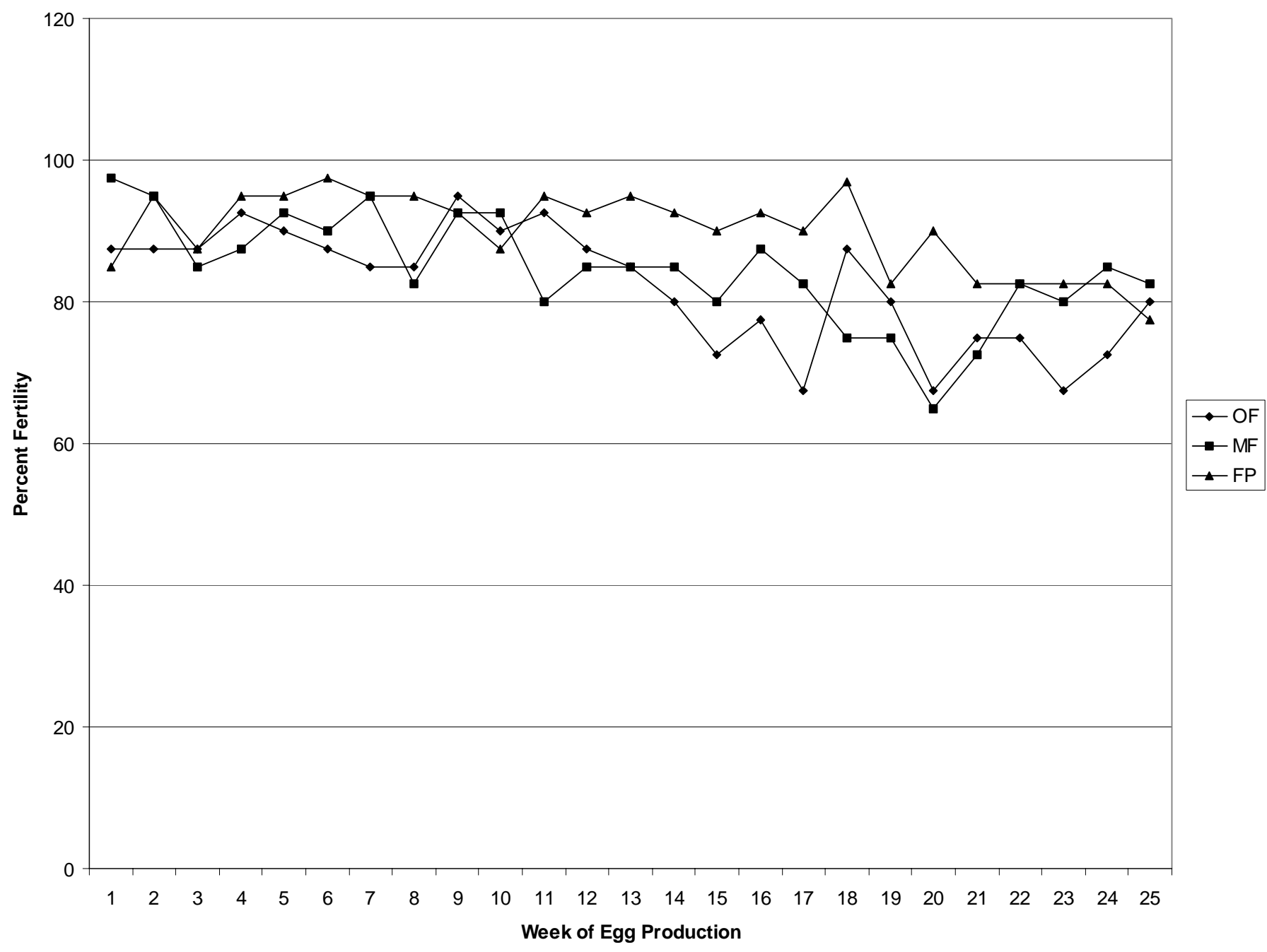

Figure 2.2. Weekly fertility percentage comparing slat-floor pens (FP), colony cages with original floors (OF), and colony cages with modified floors (MF). 


\section{Discussion}

\section{Fertility}

The data in the first experiment shows the slat-floor pen to have a significantly higher fertility than the colony cage units. This can be attributed in part to a large number of enlarged foot pads observed on the males in the cages, indicating a need for a flooring of a different design. The presence and design of the perches in the colony cages (Tauson and Abrahamsson, 1994; Abrahamsson et al., 1996) may also cause bumblefoot (lesions on the foot pads). The lower level of fertility can also be partly attributed to a slight reluctance in the females to mate on the slatted cage floors as seen in other studies. It is commonly known that hens housed in slat-litter pens tend to allow mating more readily when they are on the litter portion of the pan as opposed to the slats. The influence of these factors would be enough to create the $7.4 \%$ fertility difference between the two treatments in the first experiment.

In the second experiment, a modified floor was used in half of the colony cages, and males with sore footpads were replaced with healthy males throughout the experiment across all treatments. This was done to reduce the influence of males with sore foot pads on fertility. Although the fertility in the slat-floor treatment was still significantly higher, the modified floor colony cage treatment did show a trend, though not significant, toward improved fertility over the original floor colony cage treatment. The modified floor colony cages averaged $84.4 \%$ fertility, which was only $4.7 \%$ lower than the slatfloor pens, and $2.2 \%$ higher than the original floor colony cages. The modified flooring had a two piece plastic construction. The top piece was designed to absorb shock and cushion impact, something the original floor lacked, and was perhaps slightly more 
comfortable for the hens during mating. The slats were also closer together on the modified floors, which may also have increased the comfort of the hens.

\section{Egg Quality}

Egg quality, as measured by comparing egg weight, albumin height, and shell thickness were all significantly better in eggs produced in the colony cages. The higher egg weights observed in the colony cages in these experiments is in agreement with other studies (Reece et al., 1971; Fuquay and Renden 1980; Pettite et al., 1993). Since albumin height and eggshell thickness were higher in colony cages, overall egg quality is higher in colony cages than in slat-floor pens. Higher egg quality should lead to improved hatchability.

\section{Mortality}

In both experiments, mortality in the hens showed no significant difference between treatments. This is in agreement with Petitte et al.,(1982) who observed that caged broiler breeders laid significantly heavier eggs than their floor counterparts with similar mortality rates. In the first experiment, rooster mortality was higher on the slat-floor system, however the number of foot lesions in males was higher in the colony cages (visually observed but not recorded). Rooster mortality was not recorded in the second experiment since males with sore feet and unthrifty males were replaced before they died. 


\section{Conclusions}

These experiments focused on the performance of broiler breeders maintained in colony cages versus conventional slat-floor systems using natural mating. Mortality in the hens and egg production were not significantly different when comparing slat-floor pens and colony cages throughout both studies. Egg quality, as measured by increased egg weights, albumin height, and shell thickness, is significantly better in colony cages. This should result in better hatchability of the eggs produced by broiler breeders in colony cages, and a faster growing offspring. Other studies show a trend toward an increased growth rate and increased feed conversion from the progeny of broiler breeders maintained in colony cages. As seen in other studies, fertility was lower in colony cages than in slat-floor systems. As also seen in a previous study, fertility declined in breeders drastically after 43 weeks of age. While rooster mortality was lower in colony cages, it was observed that a higher incidence of sore footpads in those males. This may have resulted in a reduction in mating attempts, and thereby a reduction in fertility would naturally follow. To address this problem, replacement of males was used in the second experiment. Any males showing signs of developing sore foot pads were removed and replaced with a healthy male. There was a trend toward increased fertility in the cages with the modified floors in the second experiment, however, it was not statistically different between the two cage treatments. Replacement of the males could not be solely responsible since males were also replaced in the colony cages with the original flooring, and no increase was observed. The design of the floors in the modified cages also gave a more cushioned effect, which may have aided in the comfort of the hens, and increased their willingness to mate on the slats. 
Since it is a common practice of the broiler breeder industry to increase the number of new poultry buildings when an increase in egg production is needed, the use of colony cages would allow an increase in egg production of up to 1.8 times the original number of eggs that can be produced in the same space using conventional floor pens. This can be accomplished in existing buildings by simply installing the cages and increasing the ventilation capacity. Even though the cost of the colony cages is high, they would be economically cheaper in the long run than the cost of building and maintaining new poultry buildings. Producers could use commercial colony cages in conjunction with natural mating economically up to 40 weeks. Since most studies show that fertility drops off rapidly after 40 weeks of age, more studies are recommended to overcome this problem. One area that may need more attention is in the design of the floor slats for the colony cages. 


\section{Literature Cited}

Abrahamsson, P., R. Tauson, and M. C. Appleby, 1996. Behavior, health and integument of four hybrids of laying hens in modified and conventional cages. British Poultry Sci. 37:521-540

Appleby, M., S. F. Smith, and B. O. Hughes, 1993. Nesting, dust bathing, and perching by laying hens in cages: Effects of design on behaviour and welfare. British Poultry Sci. 37:521-540

Atwood, H., 1929. Observation concerning the time factor in egg production. Poultry Sci. $8: 137-140$

Bilgilli, S. F., and J. A. Renden, 1985. Relationship of body fat to fertility in broiler breeder hens. Poultry Sci. 64:1394-1396

Bramwell, R. K., C. D. McDaniel, and J. L. Wilson, 1996. Age effect on male and female broilers on sperm penetration of perivitelline layer overlaying the germinal disc. Poultry Sci. 75:755-762

Fasenko, G. M., R. T. Hardin, and F. E. Robinson, 1992. Relationship of hen age and sequence position with fertility, hatchability, viability and pre-incubation embryonic development in broiler breeders. Poultry Sci. 71:1374-1383

Fauquay, J. I., and J. A. Renden, 1980. Reproductive performance of broiler breeders maintained in cages or on the floor through 59 weeks. Poultry Sci. 59:2525-2531 Lessen S., and J. D. Summers, 1985. Effect of cages versus floor rearing and skipa-day feed restriction on performance of dwarf broiler breeders and their offspring. Poultry Sci. 64:1742-1749 
Mcdaniel, G. R., J. Brake, snd M. K. Echman, 1981. Factors affecting broiler breeders performance. 4 . The interrelationship of some reproductive traits. Poultry Sci. 60:1792-1797

North, O. M., D. D. Bell, 1990. Commercial Chicken Production Manual. Fourth Edition. Chapman and Hall, New York, N.Y. pp913

Parker, J. E., and W. H. McClursky, 1959. Volume and fertilizing capacity of semen collected from cockerels maintained in cages and on the floor. Poultry Sci. $38: 858-860$

Petitte, J. N., R. O. Hawes, and R. U. Greny, 1982. The influence of flock uniformity on the reproductive performance of broiler breeder hens housed in cages and floor pens. Poultry Sci. 61:2116-2171

Petite, J. N., R. O. Hawes, and R. W. Gerry, 1983. The influence of cage versus management of broiler hens on subquent performance of cage reared broilers. Poultry Sci. 62:1241-1246

Proudfoot, F. G., and H. W. Hullan, 1981. The influence of hatching egg size on the subsequent performance of broiler chickens. Poultry Sci. 60:2167-2170

Reece, F. N., J. W. Deaton, J. D. May, and K. N. May, 1971. Cage versus floor rearing of broiler chickens. Poultry Sci. 45:1418-1419

Robinsin, F. E., T. A. Wauter, R. T. Hardin, N. A. Robinson, J. L. Wilson, M. Newcombe, and R. I. McKay, 1996. Effects of age at photo stimulation on reproductive efficiency and characteristics. 1. Broiler breeder hens. Canadian J. of Animal Sci. 76:275-282 
Robinson, F. E., R. T. Hardin, and A. R. Roblee, 1990. Reproductive senescence in domestic fowl: Egg production sequence length and intersequence pause length. Br. Poultry Sci. 31:871-879

Tindell, D., and D. R. Morris, 1964. The effects of egg weight on subsequent broiler performance. Poultry Sci. 43:534-539

Tauson, R., and P. Abrahamsson, 1994. Foot and skeletal disorders in laying hens. Effects of perch design, hybrid, and housingsystem and stocking density. Acta Agriculturae Scandinavica. Section A, Animal Sci. 44:110-119

Yu, M. W., and F. E. Robinson, 1992. The application of short term feed restriction to broiler chicken production. A. review. Applied Poultry Research. 1:147-153 


\section{Appendix}

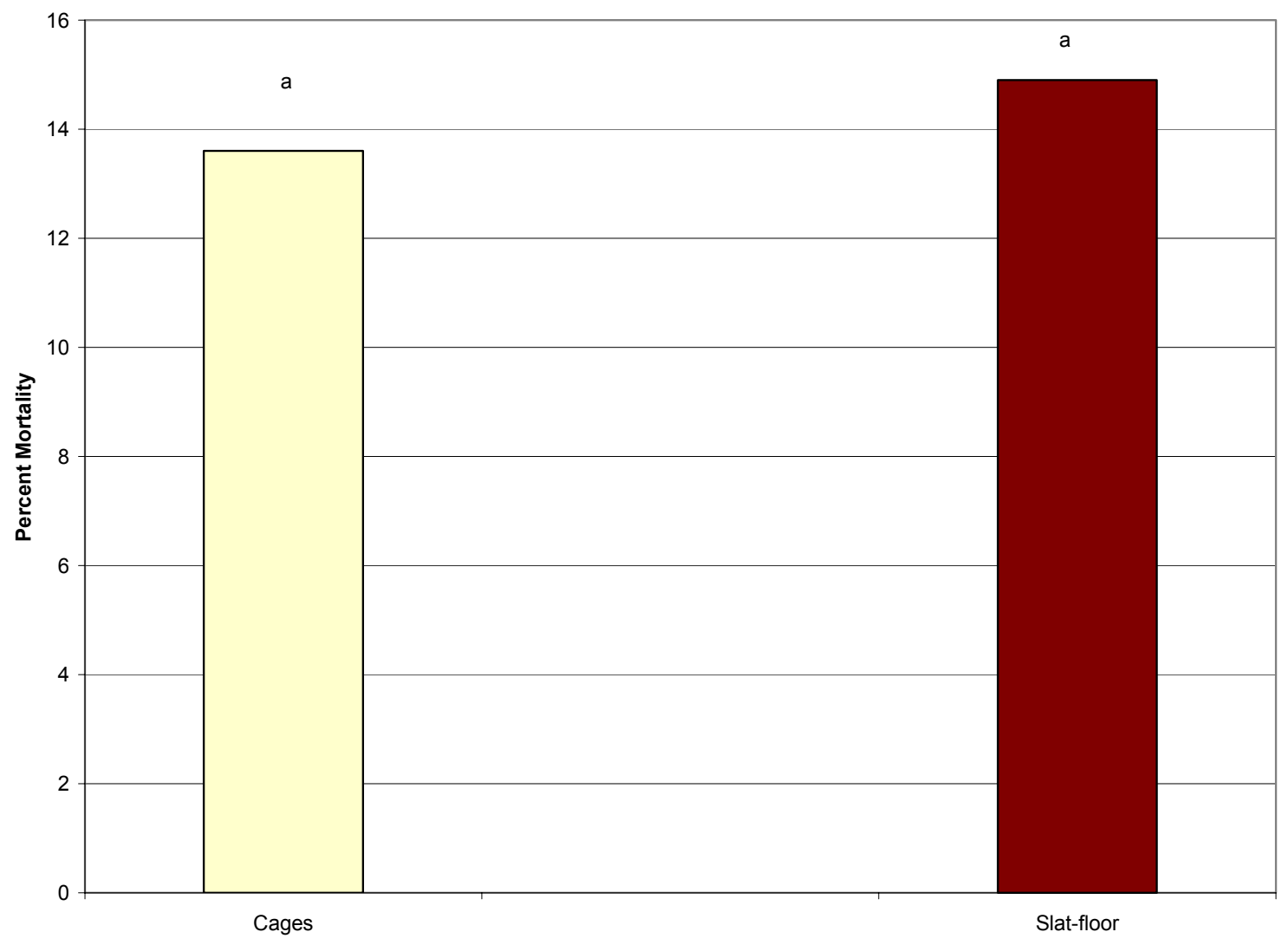

Figure 1.3. Average mortality comparing slat-floor and colony cage maintained hens. 


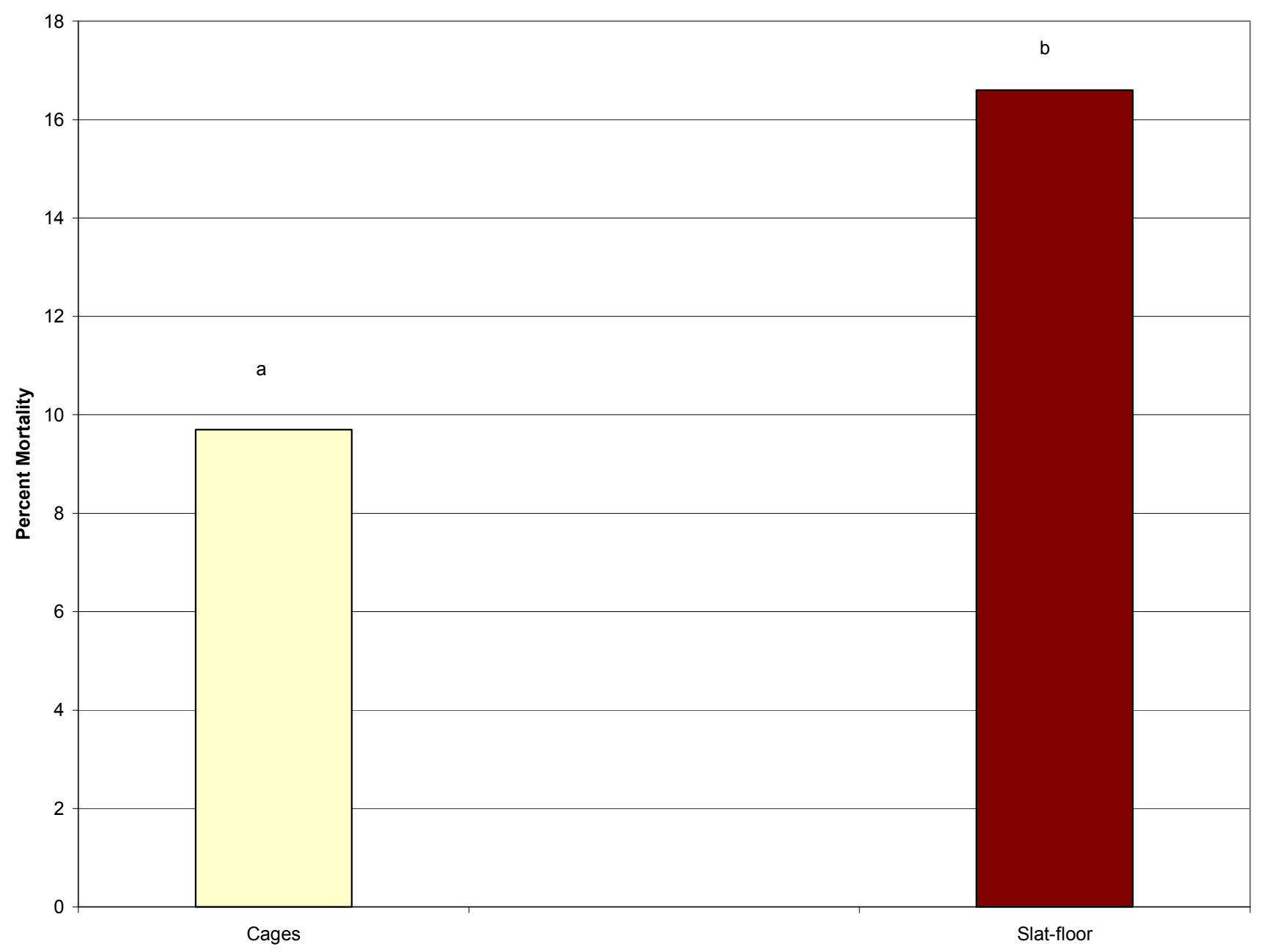

Figure 1.4. Average mortality comparing slat-floor and colony cage maintained roosters. $(\mathrm{P}<0.05)$ 


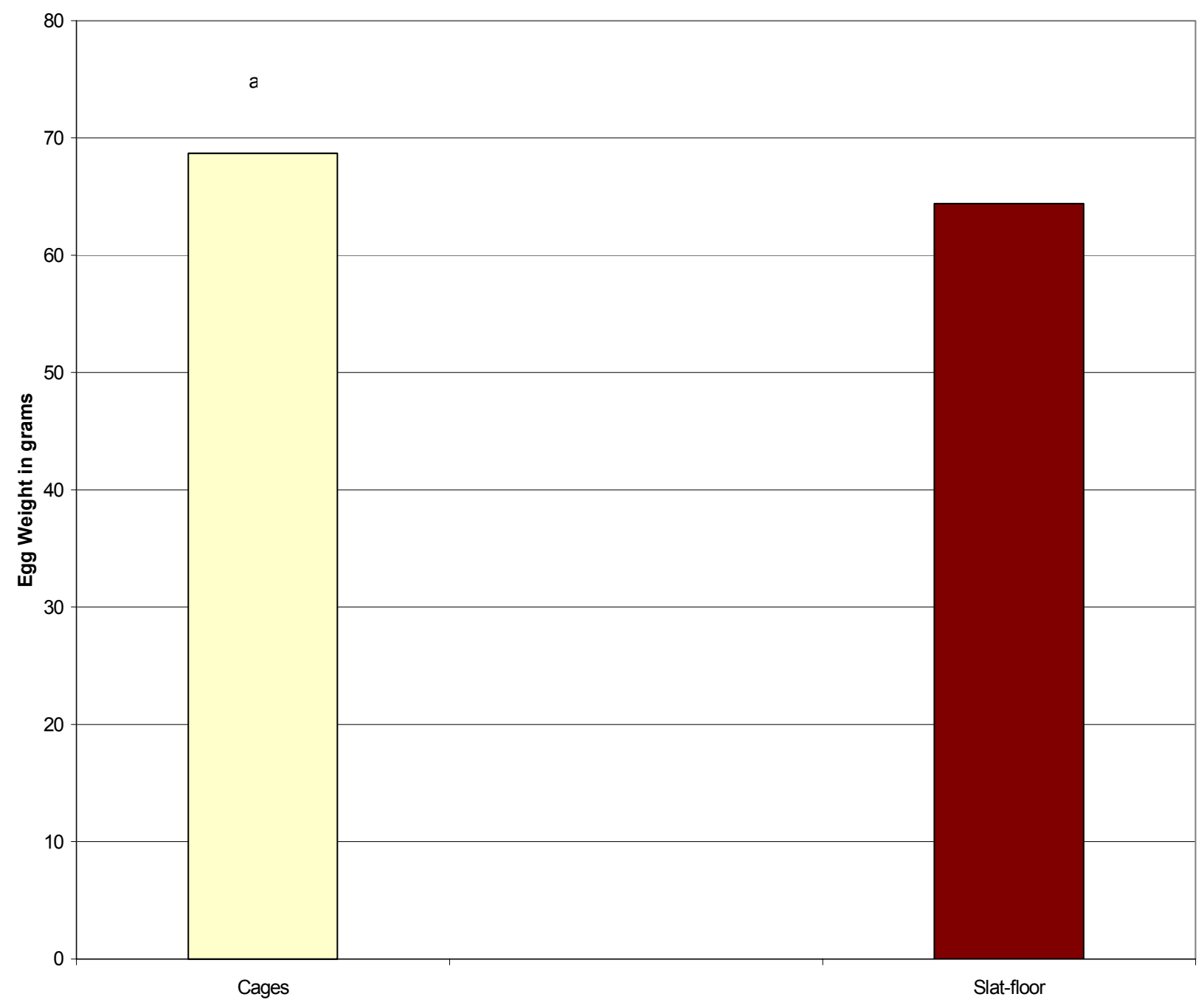

Figure 1.5. Average egg weights comparing slat-floor pens and colony cage maintained hens. $(P<0.05)$ 


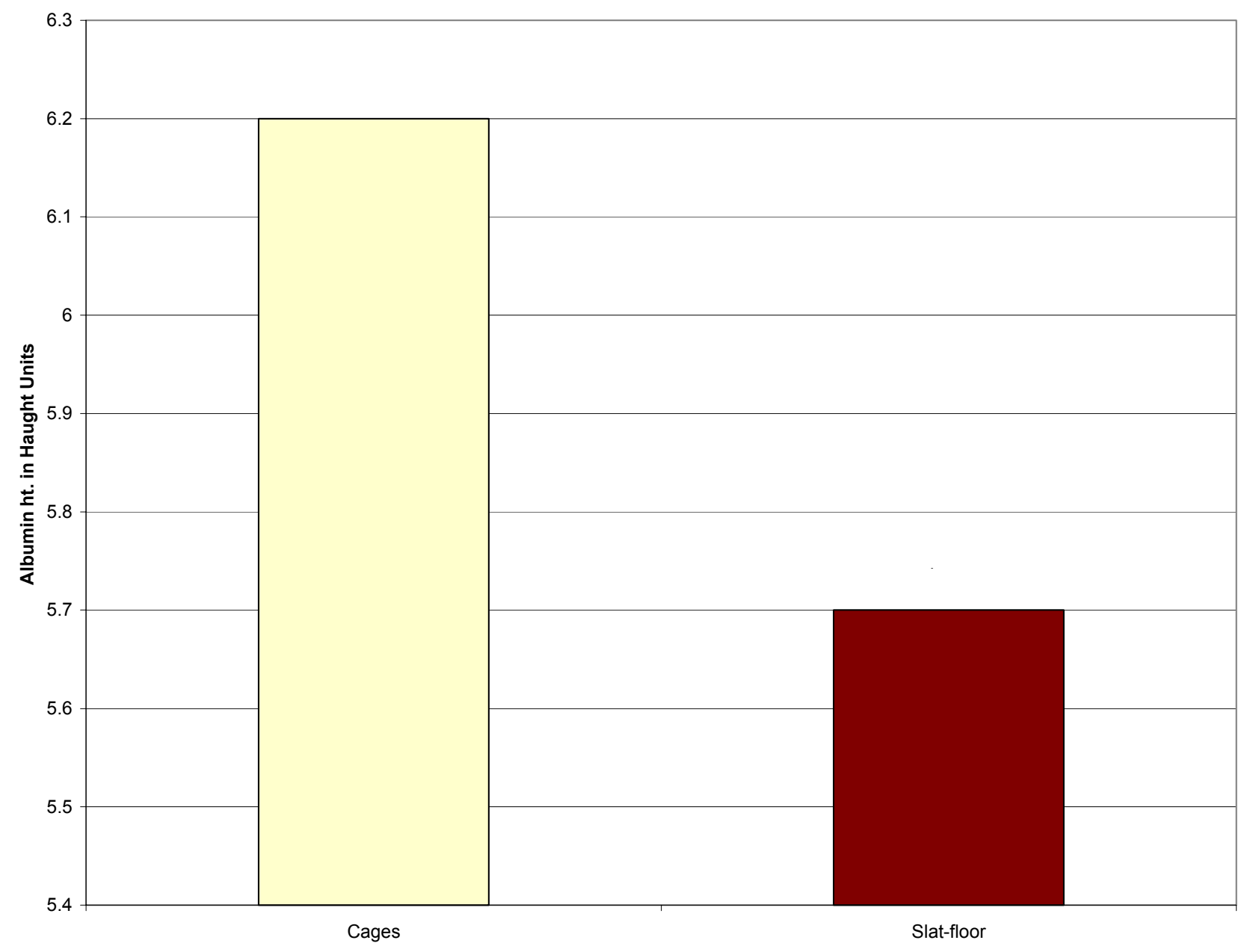

Figure 1.6. Average albumin height comparing slat-floor pens and colony cages. $(\mathbf{P}<\mathbf{0 . 0 5})$ 


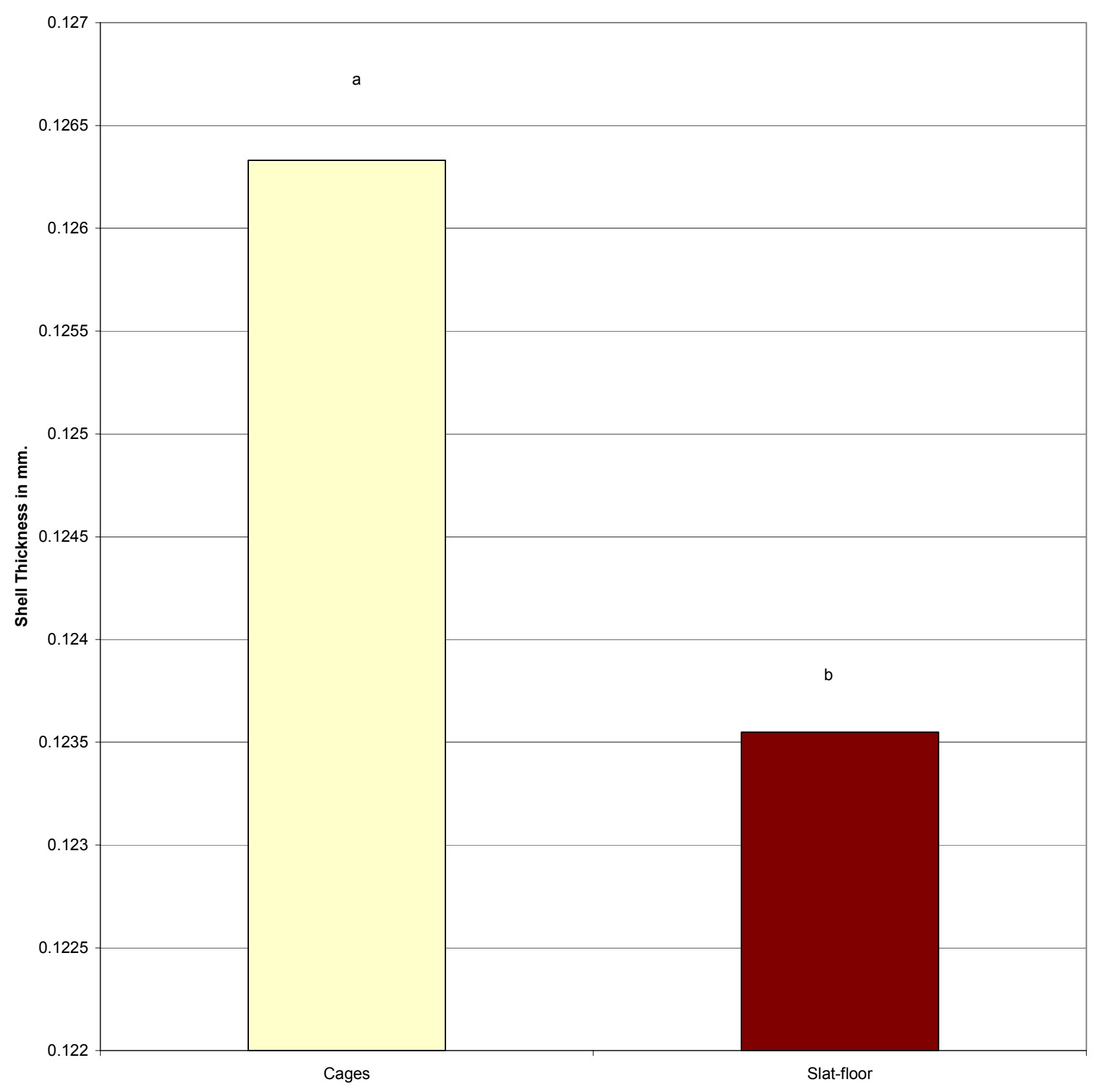

Figure 1.7. Average eggshell thickness comparing slat-floor pens and colony cages. $(\mathbf{P}<\mathbf{0 . 0 5})$ 


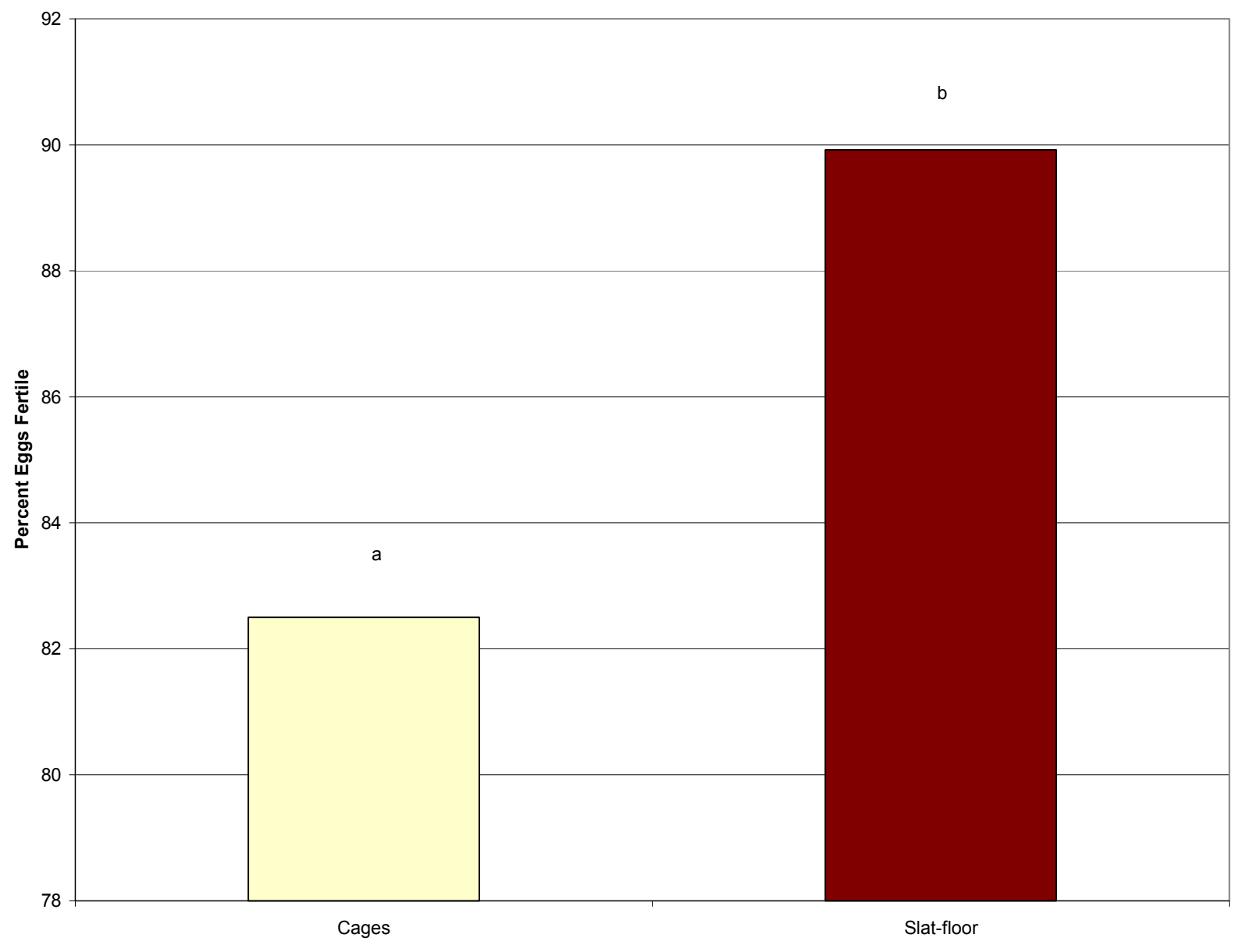

Figure 1.8. Average percent of fertile eggs produced comparing slat-floor and colony cages. $(P<0.05)$ 


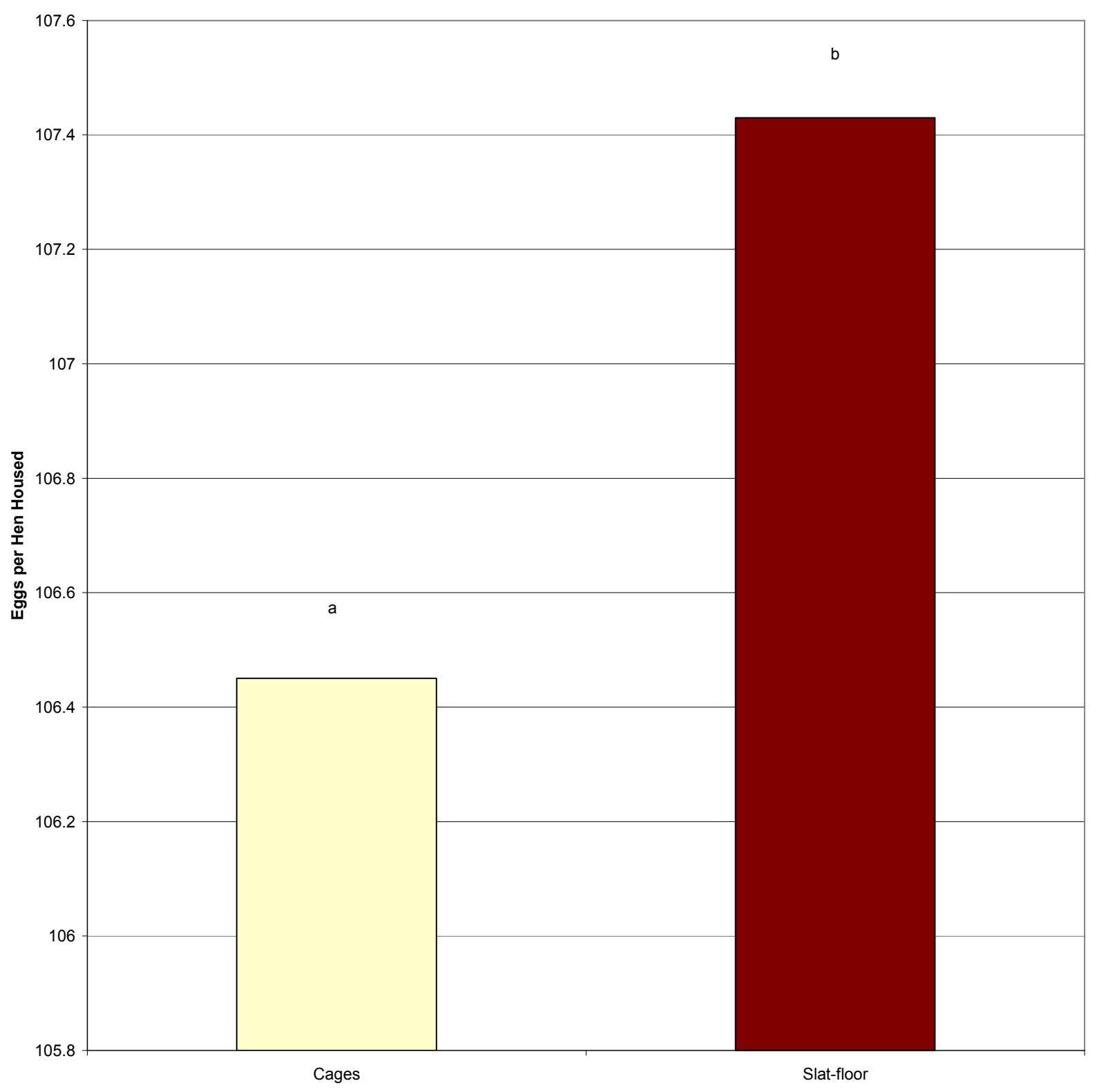

Figure 1.9. Average eggs per hen housed comparing slat-floor pens and colony cages. $(\mathbf{P}<\mathbf{0 . 0 5})$ 


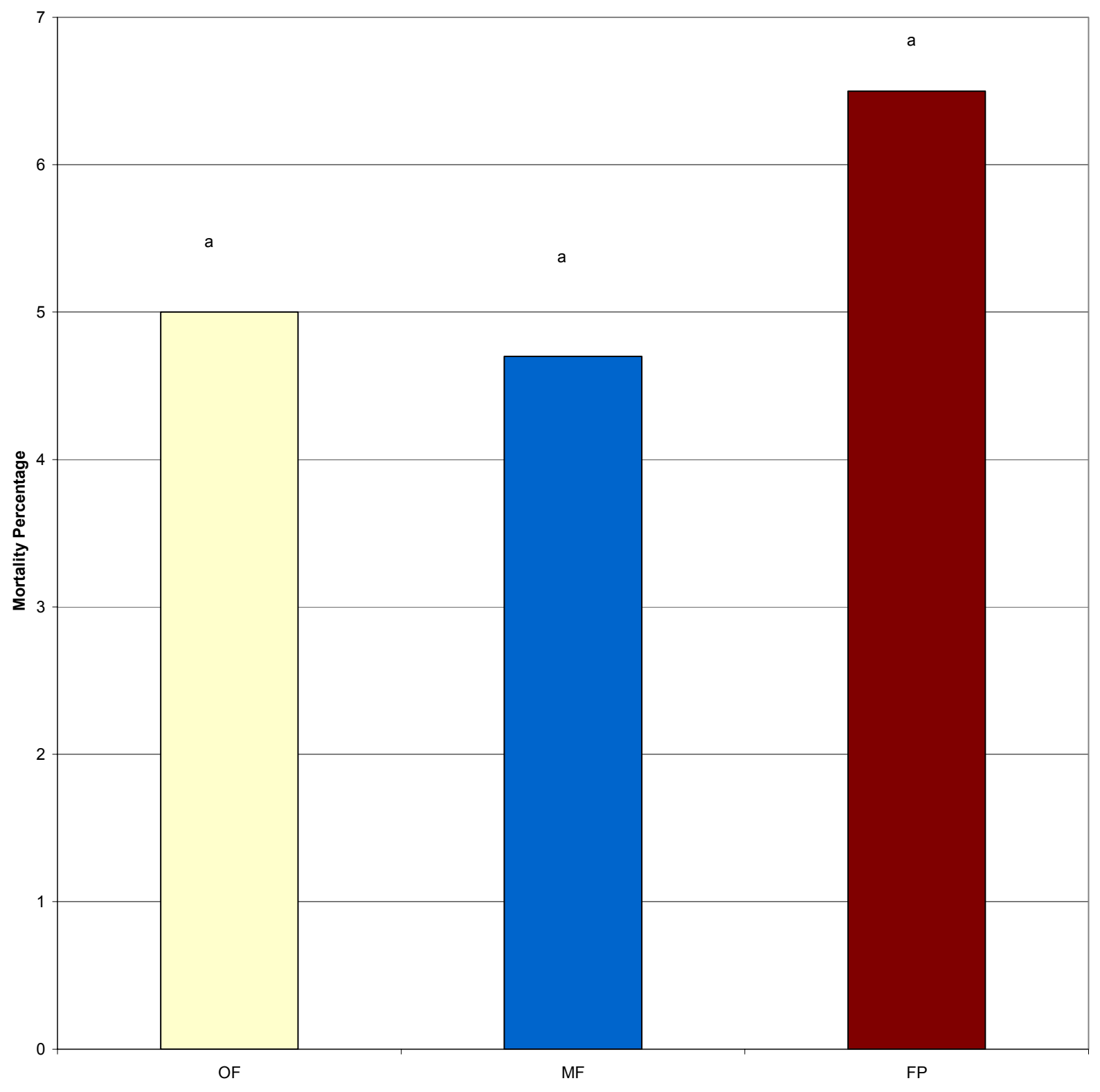

Figure 2.3. Average hen mortality comparing slat-floor pens (FP), colony cages with original floors $(\mathrm{OF})$, and colony cages with modified floors $(\mathrm{MF}) .(\mathrm{P}<0.05)$ 


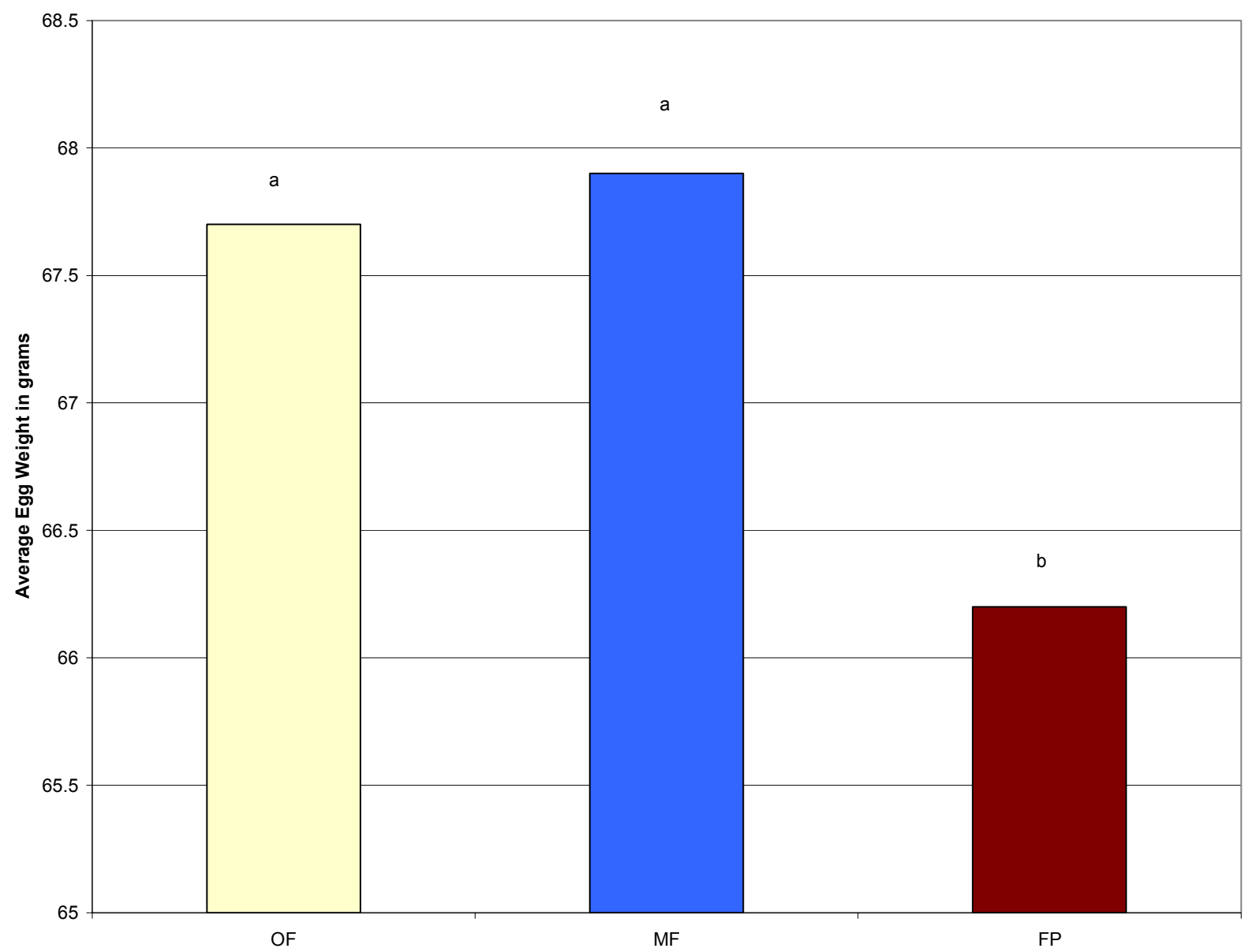

Figure 2.4. Average egg weights comparing slat-floors (FP), colony cages with original floors (OF), and colony cages with modified floors $(\mathrm{MF}) .(\mathrm{P}<0.05)$ 


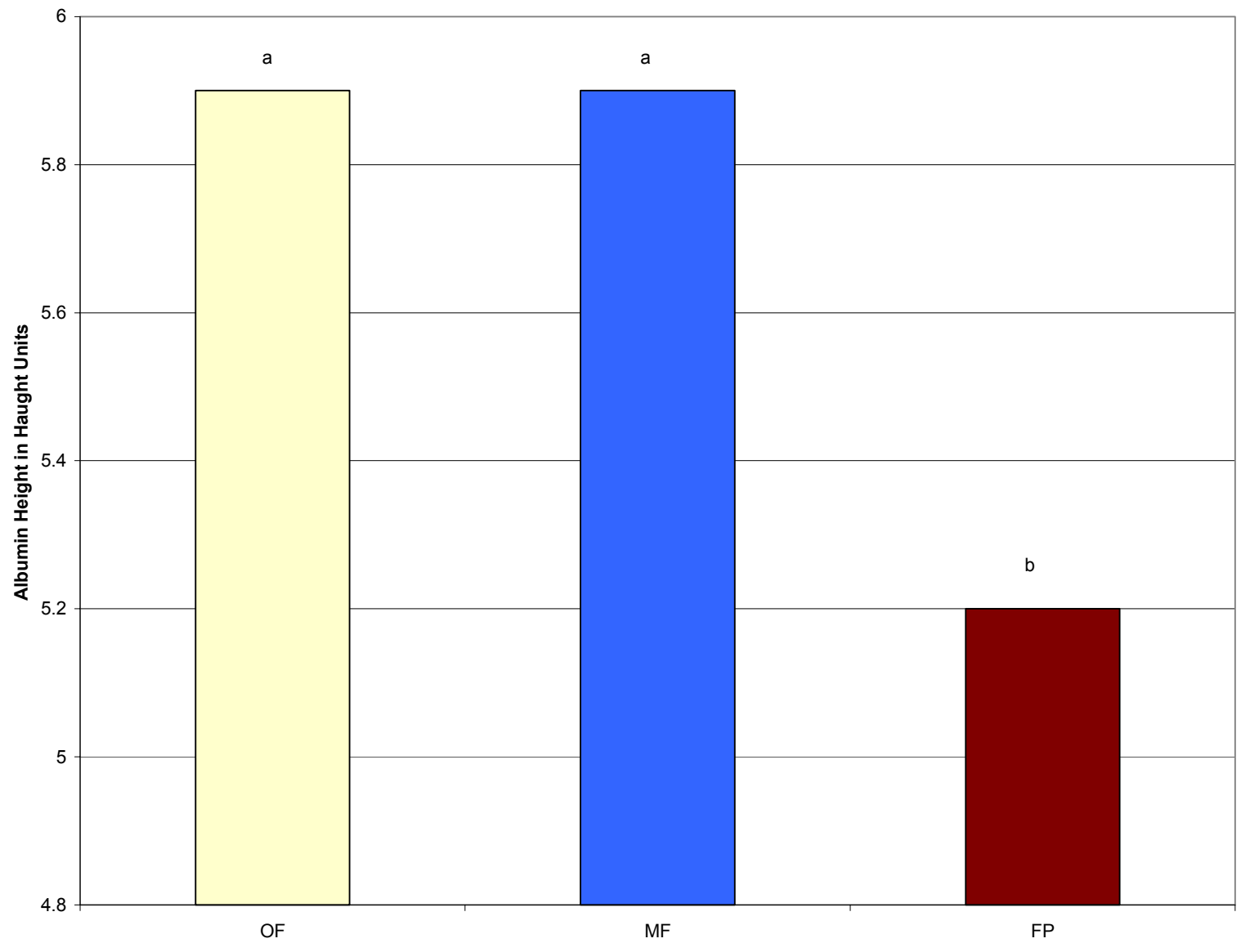

Figure 2.5. Average albumin height comparing slat-floor pens (FP), colony cages with the original floors $(\mathrm{OF})$, and colony cages with modified floors $(\mathrm{MF}) .(\mathrm{P}<0.05)$ 


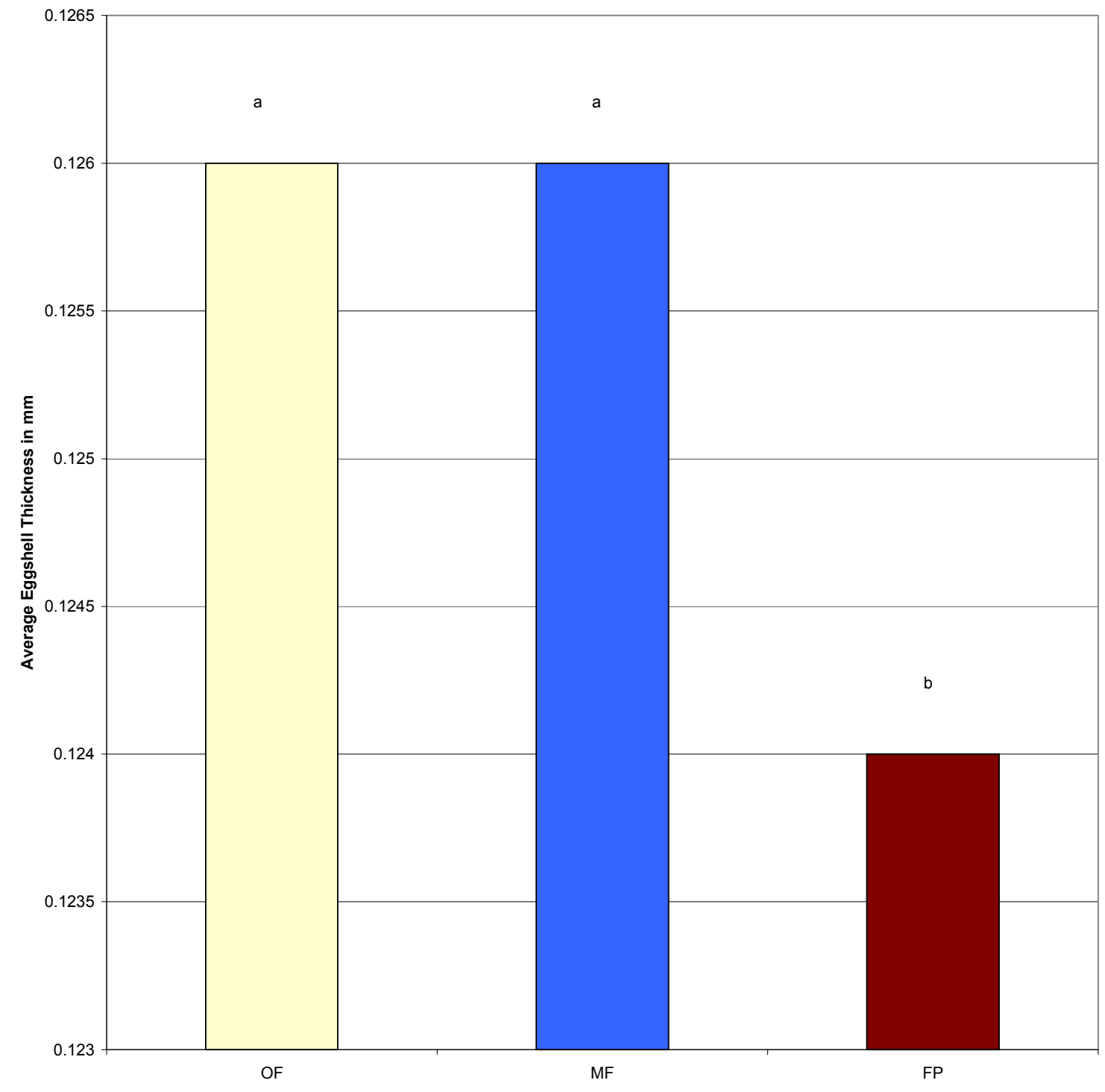

Figure 2.6. Average eggshell thickness comparing slat-floor pens (FP), colony cages with original floors (OF), and colony cages with modified floors $(\mathrm{MF}) .(\mathrm{P}<0.05)$ 


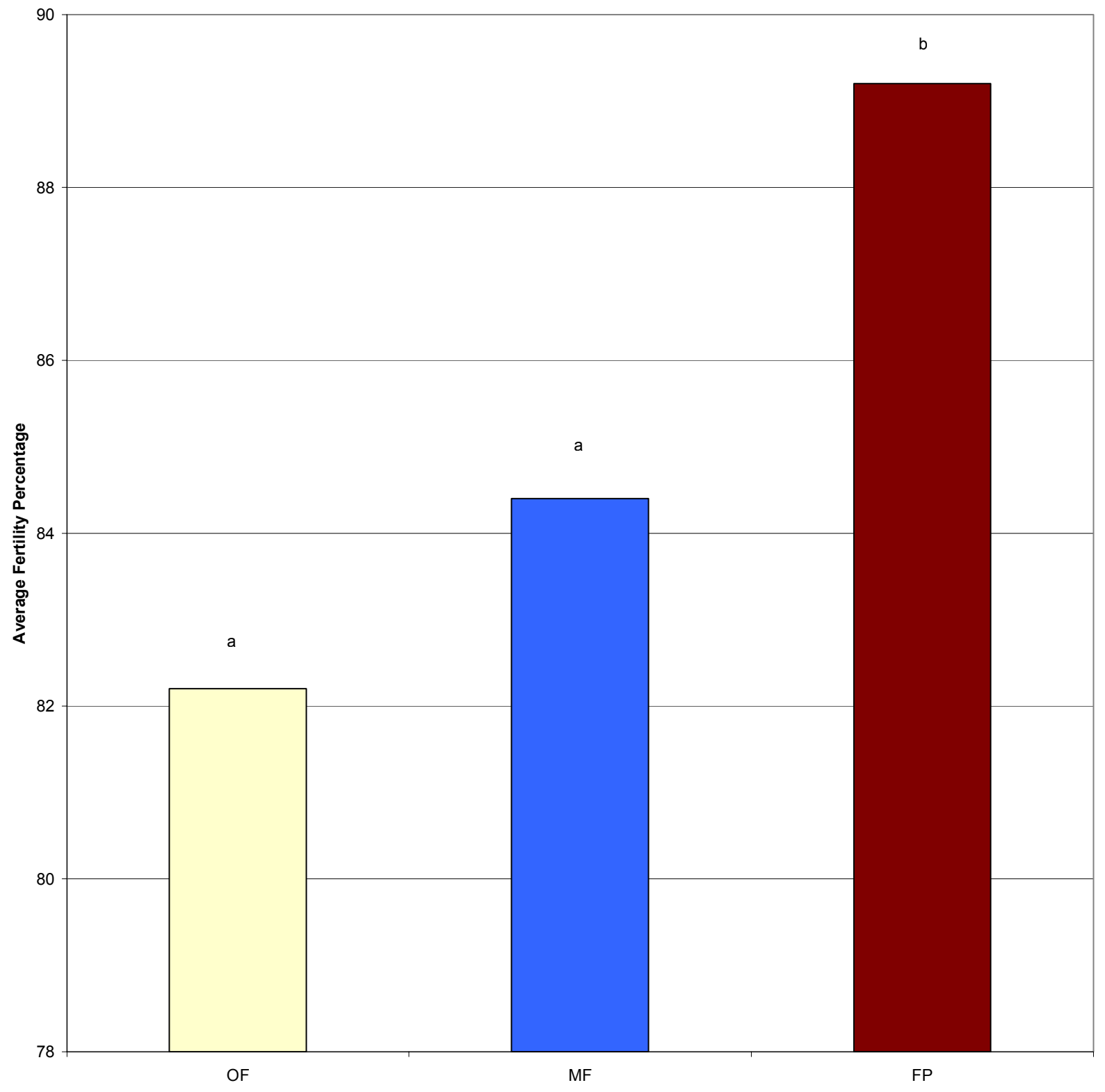

Figure 2.7. Average fertility percentage comparing slat-floor pens (FP), colony cages with original flooring $(\mathrm{OF})$, and colony cages with modified flooring $(\mathrm{MF}) .(\mathrm{P}<0.05)$ 


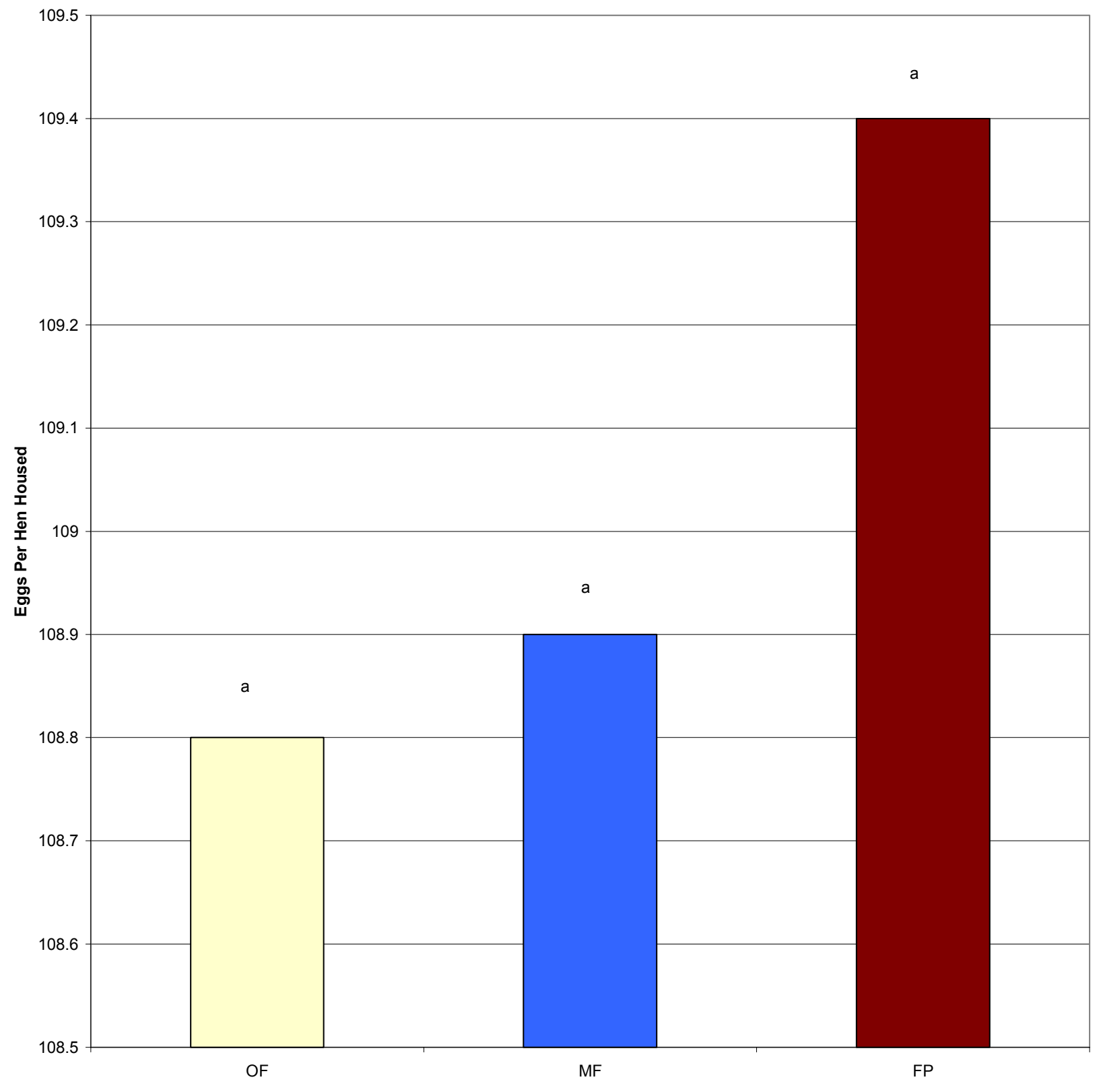

Figure 2.8. Average eggs per hen housed comparing slat-floor pens (FP), colony cages with original flooring $(\mathrm{OF})$, and colony cages with modified flooring $(\mathrm{MF}) .(\mathrm{P}<0.05)$ 
Curriculum Vitae

\author{
Joe Massey \\ 3171 Grafton Road \\ Morgantown, WV 26508 \\ (304)291-0940
}

Education:

West Virginia University, Morgantown, WV

Master of Animal Science - Nutrition

Graduation Expected May 2002

Graduate Research Assistant - Animal Science

West Virginia University, Morgantown, WV

Bachelor of Agriculture

May 1996

Professional Experience:

2001 Chief Animal Control Officer, Monongalia County WV

Serve the community by enforcing the animal control regulations in the county. Supervise a staff of four, as well as a budget of over $\$ 160,000$.

2001-1999 Graduate Assistant, West Virginia University Dept. of Animal Sci. Taught animal physiology lab, animal nutrition, animal production. Assisted with research projects related to poultry production.

1999-1996 Agricultural Extension Agent, NC Cooperative Extension Service Poultry and Tobacco

North Carolina State University

Iredell County, Statesville, NC

Developed a comprehensive education and research program for agricultural producers in poultry and tobacco production. Compost and nutrient management were of special note in my programming activities. Team member for development of nutrient management training materials for NC poultry producers. Trained 1200+ producers in nutrient management plan design. Worked directly with the public in identifying problems and helping to answer questions.

1992- 1990 Farm Manager-British United Turkeys of America Lewisburg, WV Managed a team of 12 farm workers in the production of commercial turkey laying flocks. Responsible for all areas of farm 
management including budget, purchasing, maintenance and management of flock.

1989-1988 Farm Worker - British United Turkeys of America Lewisburg, WV

Worked as a member of the farm crew in commercial turkey laying flock production.

\section{7-1984 Farm Manager - Connell Farms}

Sinks Grove, WV

Responsible for management of 300 head steer lot, production of hay and grain crops and maintenance of farm equipment.

1983-1979 Herd Manager - Kirby Dairy

Sinks Grove, WV

Responsible for management of 60 cow dairy herd, production of hay and grain crops, maintenance of equipment and management of 75 ewe sheep flock.

Professional Memberships:

National Association of County Agricultural Agent

1996-99

Grants:

Water Quality Programming Grant - North Carolina $\$ 10,000$

Department of Environmental Protection - 1999

Professional Development:

North Carolina Waste Management Certification

Extension Program Planning Graduate Course 1997 North Carolina State University 